ISSN : 2580-3220, E-ISSN : 2580-4588

J. Mandiri., Vol. 2, No. 1, Juni 2018 (87 - 107)

(C)2018 Lembaga Kajian Demokrasi

dan Pemberdayaan Masyarakat (LKD-PM)

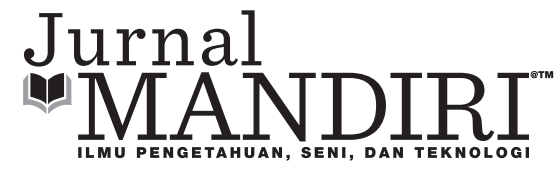

\title{
ANALISIS PEREKONOMIAN DAN POTENSI EKONOMI KREATIF TANGERANG SELATAN
}

\author{
Nefo Indra Nizar \\ Fakultas Ekonomi, Universitas Pamulang \\ nefoindra@gmail.com
}

\begin{abstract}
Abstrak
Tangerang Selatan sebagai kota yang relatif baru, terus melakukan proses pembangunan ekonomi secara berkelanjutan. Untuk itu perlu diperhatikan dan dikembangkan apa saja yang menjadi sektor unggulan. Disamping potensi ekonomi kreatif yang sangat besar, pada gilirannya akan menambah pendapatan dan meningkatkan perekonomian. Tujuan dari penelitian ini adalah untuk menganalisis perekonomian, struktur perekonomian, sektor unggulan, potensi ekonomi kreatif, serta bagaimana strategi pengembangan ekonomi kreatif kota Tangerang Selatan. Metode penelitian menggunakan data sekunder dengan analisis pertumbuhan ekonomi, struktur ekonomi dan kontribusi sektoral terhadap PDRB, analisis $L Q$, dan analisis Shift Share. Untuk mengetahui potensi ekonomi kreatif dan pengembangan strategi ke depan, digunakan analisis SWOT dengan pendekatan tujuh dimensi ekonomi kreatif. Hasil penelitian menunjukkan pertumbuhan Tangerang Selatan paling tinggi dibandingkan dengan kota/kabupaten se Banten. Struktur ekonomi paling besar di sektor tersier. Berdasarkan analisis LQ terdapat sembilan lapangan usaha yang menjadi sektor unggulan, atau sektor basis dengan nilai LQ > 1. Dari analisis Shift Share (SS) kota Tangerang Selatan terhadap provinsi Banten periode tahun 2012-2016, menunjukkan nilai pertumbuhan aktual $(P R)>$ Regional Share (RS), secara keseluruhan pertumbuhan kota Tangerang Selatan relatif lebih tinggi dibandingkan dengan provinsi Banten. Nilai Differential Shift (DS) positif, menunjukkan keungguan komparatif yang cukup tinggi. Nilai Proportional Shift (PS), juga menunjukkan secara proporsional komposisi sektor-sektor industri tumbuh lebih cepat dibandingkan dengan provinsi Banten. Berdasarkan tujuh dimensi ekonomi kreatif yang digunakan, melalui analisis SWOT, perlu dikembangkan secara keseluruhan. Dari tujuh dimensi tersebut, ada dua dimensi yang menjadi prioritas dan perhatian. Pertama adalah masalah pengembangan sumber daya manusia dan kedua adalah masalah pembiayaan atau permodalan.
\end{abstract}

Kata Kunci : Analisis LQ, Analisis Shift Share, Differential Shift, Proportional Shift, Analisis SWOT, Sektor Unggulan, Ekonomi Kreatif 


\section{PENDAHULUAN}

\section{Latar Belakang}

Tangerang Selatan adalah kota yang relatif baru terbentuk, sebagai daerah otonom bagian dari propinsi Banten. Sesuai UU No. 51 Tahun 2008 mengenai keputusan pembentukan kota Tangerang Selatan, adalah bertujuan untuk meningkatkan pelayanan dalam bidang pemerintahan, pembangunan, dan kemasyarakatan, serta dapat memberikan kemampuan dalam pemanfaatan potensi daerah.

Salah satu indikator perekonomian untuk dapat melihat proses pembangunan yang berkelanjutan adalah laju pertumbuhan ekonomi. Kota Tangerang Selatan berdasarkan data BPS Banten menunjukkan tingkat laju pertumbuhan yang paling tinggi dibandingkan dengan kabupaten/kota se propinsi Banten, yaitu sebesar 7,2\% pada tahun 2015 dan $6,98 \%$ pada tahun 2016.

Tabel-1

Pertumbuan Ekonomi Kabupaten/Kota se Banten 2015 - 2016

\begin{tabular}{|l|c|c|}
\multirow{2}{*}{\multicolumn{1}{c|}{ Kabupaten/Kota }} & \multicolumn{2}{c|}{$\begin{array}{c}\text { Pertumbuhan Ekonomi } \\
\text { ADH Konstan 2010 }\end{array}$} \\
\cline { 2 - 3 } & $\mathbf{2 0 1 5}$ & $\mathbf{2 0 1 6}$ \\
\hline Kabupaten Pandeglang & 5,96 & 5,49 \\
\hline Kabupaten Lebak & 5,8 & 5,7 \\
\hline Kabupaten Tangerang & 5,36 & 5,32 \\
\hline Kabupaten Serang & 5,02 & 5 \\
\hline Kota Tangerang & 5,37 & 5,3 \\
\hline Kota Cilegon & 4,78 & 5,05 \\
\hline Kota Serang & 6,29 & 6,22 \\
\hline Kota Tangerang Selatan & 7,2 & 6,98 \\
\hline
\end{tabular}

Sumber : BPS, PDRB Provinsi Banten (2015 - 2016)

Sementara dilihat dari struktur perekonomian kota Tangerang Selatan didominasi oleh pedagang besar dan eceran, dan reparasi mobil dan sepeda motor sekitar 17,56\% dengan nilai nominal 8,977 triliyun rupiah. Kategori penyumbang kedua adalah real estate sebesar $16,21 \%$ atau senilai 8,302 triliun rupiah. Kate gori penyumbang ketiga adalah konstruksi sebesar $15,02 \%$ atau sebesar 7,690 triliyun rupiah.

Tabel-2

Struktur Perekonomian Kota Tangerang

Selatan Menurut Kategori, 2012 - 2014

\begin{tabular}{|c|c|c|c|c|}
\hline & \multirow{2}{*}{ Lapangan Usaha } & \multicolumn{3}{|c|}{ Share } \\
\hline & & 2012 & 2013 & 2014 \\
\hline & (1) & (2) & (3) & (4) \\
\hline$A$ & $\begin{array}{l}\text { Pertanian, Kehutanan } \\
\text { dan Perikanan }\end{array}$ & 0,30 & 0,29 & 0,32 \\
\hline B & \begin{tabular}{|l} 
Pertambangn dan \\
Penggalian
\end{tabular} & 0,00 & 0,00 & 0,00 \\
\hline$C$ & Industri Pengolahan & 11,84 & 11,62 & 11,45 \\
\hline D & $\begin{array}{l}\text { Pengadaan Listrik dan } \\
\text { Gas }\end{array}$ & 0,11 & 0,12 & 0,12 \\
\hline$E$ & \begin{tabular}{|l} 
Pengadaan Air, \\
Pengelolahan sampah, \\
Limbah dan Daur Ulang
\end{tabular} & 0,05 & 0,05 & 0,04 \\
\hline $\mathrm{F}$ & Konstruksi & 13,55 & 14,39 & 15,01 \\
\hline G & \begin{tabular}{|l|} 
Perdagangan Besar, \\
Eceran, Reparasi Mobil \\
dan Sepeda Motor
\end{tabular} & 18,63 & 17,95 & 17,56 \\
\hline $\mathrm{H}$ & \begin{tabular}{|l|}
$\begin{array}{l}\text { Transportasi dan } \\
\text { pergudangan }\end{array}$ \\
\end{tabular} & 2,70 & 2,91 & 3,07 \\
\hline 1 & $\begin{array}{l}\text { Penyediaan akomodasi } \\
\text { dan Makan Minum }\end{array}$ & 3,14 & 3,22 & 3,36 \\
\hline $\mathrm{J}$ & $\begin{array}{l}\text { Informasi dan } \\
\text { Komunikasi }\end{array}$ & 11,94 & 10,91 & 10,86 \\
\hline K & $\begin{array}{l}\text { Jasa Keuangan dan } \\
\text { Asuransi }\end{array}$ & 1,22 & 1,22 & 1,21 \\
\hline$L$ & Real Estate & 16,46 & 16,65 & 16,21 \\
\hline$M, N$ & Jasa Perusahaan & 3,12 & 3,28 & 3,42 \\
\hline 0 & \begin{tabular}{|l} 
Administrasi \\
Pemerintahan, \\
Pertahanan dan \\
Jaminan Sosial Wajib \\
\end{tabular} & 1,21 & 1,20 & 1,25 \\
\hline$P$ & Jasa Pendidikan & 8,19 & 8,73 & 8,96 \\
\hline$Q$ & $\begin{array}{l}\text { Jasa Kesehatan dan } \\
\text { Kegiatan Sosial }\end{array}$ & 4,58 & 4,35 & 4,05 \\
\hline $\mathrm{R}, \mathrm{S}, \mathrm{T}, \mathrm{U}$ & Jasa lainnya & 2,95 & 3,12 & 3,14 \\
\hline $\begin{array}{l}\text { PRODU } \\
\text { REGIOI }\end{array}$ & $\begin{array}{l}\text { JK DOMESTIK } \\
\text { NAL BRUTO }\end{array}$ & 100,00 & 100,00 & 100,00 \\
\hline
\end{tabular}

Sumber : BPS, Indikator Ekonomi Tangerang Selatan 2015

Pembangunan kota Tangerang Selatan, sebagai kota baru harus terus dilakukan secara berkelanjutan. Heri Apriyanto (2015: 261) menyebutkan agar pembangunan kota dapat berkelanjutan maka diperlukan kebijakan yang mengharmoniskan tatanan ekonomi, tatanan ekologis, dan tatanan sosial. Hal tersebut dimaksudkan untuk menjamin adanya 
keberlanjutan dalam pemanfaatan sumberdaya alam yang tersedia, tanpa mengurangi peluang generasi yang akan datang untuk menikmati kondisi yang lebih baik.

Pratama Rahardja (2014:377) menyebutkan pengertian pembangunan berkelanjutan adalah pembangunan yang memenuhi kebutuhan masa kini tanpa mengurangi kemampuan generasi mendatang untuk memenuhi kebutuhan mereka sendiri.

Selain tetap memperhatikan dan mengembangkan sektor unggulan, pemerintah kota tangerang selatan perlu memperhatikan potensi ekonomi daerah. Salah satu potensi ekonomi daerah adalah mengembangkan potensi ekonomi kreatif.

Ekonomi kreatif telah menjadi sektor yang menjanjikan dalam perekonomian nasional dan diharapkan mampu menjadi kekuatan baru ekonomi nasional di masa yang akan datang. Berdasarkan data survey dan hasil statistik Badan Ekonomi Kreatif dan BPS (2016), menunjukkan bahwa PDB Ekonomi kreatif tumbuh sebesar $4,38 \%$ pada tahun 2015 , yaitu dari 784,82Triliun pada tahun 2014 menjadi sebesar 852,24 Triliun pada tahun 2015.

Tangerang Selatan memiliki potensi ekonomi kreatif di segala bidang. Tangerang Selatan memiliki real estate, perumahan dan apartment yang tersebar, disamping juga dikenal sebagai pusat kuliner. Selain itu juga memiliki seni dan budaya, serta memiliki talenta-talenta kreatif yang diwakili oleh rakyat urban (Kreatif ed2, 2015). Untuk itu perlu adanya pemetaan potensi ekonomi kreatif, yang pada gilirannya akan memberikan kontribusi kepada PDRB dan pertumbuhan ekonomi daerah.

Penelitian ini mencoba melakukan analisis perekonomian Tangerang Selatan dan posisinya sebagai salah satu kabupaten/ kota provinsi Banten, dan juga mencoba menggali potensi ekonomi kreatif yang bisa dikembangkan dan secara nyata dapat memberikan nilai tambah kepada Pendapatan
Daerah yang tidak saja memberikan tingkat laju pertumbuhan daerah, tetapi juga memberikan kesejahteraan kepada penduduk dan masyarakat Tangerang Selatan.

\section{Perumusan Masalah}

Berdasarkan uraian di atas, maka masalah yang hendak diteliti adalah sebagai berikut :

a. Bagaimana struktur perekonomian Tangerang Selatan dan sektor-sektor apa saja yang termasuk unggulan kota Tangerang Selatan?

b. Bagaimana potensi dan pemetaan ekonomi kreatif kota Tangerang Selatan?

c. Bagaimana pengembangan potensi ekonomi kreatif kota Tangerang Selatan dan strategi apa yang dapat dijalankan?

\section{Batasan Masalah}

Didalam penelitian ini diberikan pembatasan pokok masalah, yaitu sebagai berikut :

a. Data analisis perekonomian dan sektor unggulan, digunakan adalah data BPS periode 2012 - 2016.

b. Data sekunder digunakan adalah data PDRB kota Tangerang Selatan dan PDRB provinsi Banten selama periode waktu 2012 - 2016.

c. Pemetaan potensi ekonomi kreatif dilakukan dengan menggunakan data sekunder, pendekatan studi literatur terkait ekonomi kreatif kota Tangerang Selatan.

\section{Tujuan Penelitian}

Adapun tujuan dari penelitian ini, adalah sebagai berikut :

a. Untuk mengetahui struktur perekonomian dan sektor-sektor apa saja yang menjadi sektor unggulan kota Tangerang Selatan.

b. Untuk mengetahui potensi dan pemetaan ekonomi kreatif kota Tangerang Selatan.

c. Untuk mengetahui pengembangan potensi ekonomi kreatif dan strategi ekonomi kreatifkota Tangerang Selatan ke depannya. 


\section{TINJAUAN LITERATUR}

\section{Pembangunan, Pertumbuhan dan Struktur Ekonomi}

Menurut Prathama (2014, hal 346), pembangunan ekonomi (economic development) mempunyai arti yang lebih luas maknanya dari pertumbuhan ekonomi (economic growth). Jika konsep pertumbuhan ekonomi lebih mengacu kepada perubahan-perubahan kuantitatif, maka pembangunan ekonomi juga mencakup dimensi kualitatif. Pertumbuhan ekonomi hanya merupakan salah satu unsur pembangunan ekonomi.

Pembangunan Ekonomi $=$ Pertumbuhan Ekonomi + Perubahan-perubahan.

Sadono Sukirno $(2006,423)$, menyebutkan bahwa pertumbuhan ekonomi menerangkan atau mengukur prestasi dari perkembangan sesuatu ekonomi. Dalam perekonomian yang sebenarnya pertumbuhan ekonomi berarti perkembangan fisik produksi barang dan jasa yang berlaku di suatu negara, seperti pertambahan dan jumlah produksi barang industri, perkembangan infrastruktur, pertambahan jumlah sekolah, pertambahan produksi sektor jasa dan produksi barang modal. Untuk memberikan gambaran kasar mengenai pertumbuhan ekonomi yang dicapai oleh suatu negara, ukuran yang selalu digunakan adalah tingkat petumbuhan pendapatan rii yang dicapai.

Pembangunan ekonomi biasanya dikaitkan dengan perkembangan ekonomi di negaranegara berkembang. Pembangunan ekonomi bukan saja tertarik kepada masalah pendapatan nasional riil, tetapi juga kepada modernisasi kegiatan ekonomi, misalnya kepada usaha merombak sektor pertanian yang tradisional, masalah mempercepat pertumbuhan ekonomi, dan juga bagaimana meningkatkan tingkat pendapatan per kapita yang terus menerus (Sadono Sukirno, 2006:243).

Salah satu pelaksanaan pembangunan ekonomi adalah pembangunan wilayah. Indonesia yang memiliki wilayah yang cukup besar dan memiliki karakteristik kepulauan memerlukan pembangunan wilayah alternatif pelaksanaan pembangunan (Bagdja Muljarijadi, 2011).

Menurut Todaro, yang dikutip dari Bagdja Muljarijadi (2011), menyebutkan bahwa pembangunan wilayah merupakan suatu proses yang bersifat multidimensi, yang di dalamnya tercakup berbagai tindakan yang mengarah kepada terjadinya reorganisasi maupun reorientasi yang menyeluruh terhadap sistem ekonomi dan sosial masyarakat.

Peran masing-masing sektor perekonomian dapat dilihat dari struktur ekonomi suatu negara atau wilayah. Struktur ekonomi di Indonesia dikelompokkan ke dalam 3 sektor, yaitu sektor primer, sekunder dan tersier. Ada kecenderungan bahwa semakin tinggi laju pertumbuhan ekonomi yang membuat semakin tinggi pendapatan masyarakat per kapita, semakin cepat perubahan struktur ekonomi (Amir Mahmud, 2016:43)

Hollis Chenery mengemukan teori tentang perubahan struktur ekonomi, dikutip dari Amir Mahmud (2016: 43), menjelaskan bahwa perubahan struktur ekonomi di negara berkembang yang mengalami transformasi dari pertanian tradisional ke sektor industri sebagai penggerak utama pertumbuhan. Penelitian Chenery menunjukkan pendapatan per kapita telah mengubah pola konsumsi dari makanan dan kebutuhan pokok ke produk manufaktur dan jasa, akumulasi modal secara fisik dan SDM, perkembangan kota dan industri, penurunan laju pertumbuhan penduduk, ukuran keluarga yang kecil, sektor ekonomi yang di dominansi oleh sektor nonprimer terutama industri (Amir Mahmud, 2016:43).

\section{Ekonomi Kreatif}

Ekonomi kreatif dapat diartikan sebagai sektor ekonomi yang mengutamakan kualitas sumber daya manusia yang kreatif dan inovatif, sehingga sektor ekonomi ini sangat berkaitan dengan pemanfaatan Hak atas Kekayaan Intelektual (HAKI) yang meliputi HAKI milik privat, HAKI milik publik, dan HAKI milik komunitas (Serfiyani, 2016:48). 
Menurut John Howkins, yang dikutip dari Serfiyani (2016:49) mendefinisikan ekonomi kreatif sebagai kegiatan ekonomi yang menjadikan kreativitas, budaya, warisan budaya dan lingkungan sebagai tumpuan masa depan.

Nurmilah (2016:98) menyebutkan ekonomi kreatif merupakan sebuah konsep ekonomi yang mengintensifkan informasi dan kreativitas. Ekonomi kreatif mengandalkan ide dan stock of knowledge dari sumber daya manusia (SDM) sebagai faktor produksi utama dalam kegiatan ekonominya.

Makna kreativitas dapat dilihat sebagai kapasitas atau daya upaya untuk menghasilkan sesuatu yang unik, menciptakan solusi dari suatu masalah. Kreativitas merupakan faktor pendorong munculnya inovasi dengan memanfaatkan penemuan yang sudah ada. Kreativitas tidak hanya meningkatkan produktivitas tetapi dapat juga meningkatkan nilai tambah. Kreativitas dapat berasal dari budaya (Markusen, 2008). Ekonomi kreatif dapat menjadi pendorong pertumbuhan ekonomi berkelanjutan karena ide dan kreativitas adalah sumber daya yang senantiasa dapat diperbaharui (Nurmilah, 2016:98).

Ruang lingkup industri kreatif terdiri dari 16 subsektor ekonomi kreatif (BEKRAF, 2016), yaitu : Aplikasi \& Game; Arsitektur; Desain Interior; Desain Komunikasi Visual; Desain Produk; Fashion; Film, Animasi dan Video; Fotographi; Kriya; Kuliner; Musik; Penerbitan; Periklanan; Seni Pertunjukkan; Seni Rupa; dan Televisi dan Radio.

\section{Analisis LQ}

Analisis LQ pada industri/sektor tertentu membandingkan sumbangan (share) industri/ sektor tertentu terhadap total tenaga kerja/ output pada tingkat wilayah/lokal dengan sumbangan industri/sektor yang sama terhadap total tenaga kerja/output pada tingkat nasional (wilayah yang lebih luas, yang disebut wilayah referensi) Dimana jika sumbangan industri/ sektor wilayah lebih besar daripada sumbangan industri/sektor nasional maka porsi kelebihan dari output/tenaga kerja tersebut dapat menjelaskan tentang besarnya ekspor yang terjadi (Bagdja Muljarijadi, 2016:56). Pernyataan ini dapat dirumuskan sebagai berikut :

Dimana :

$\Rightarrow$ LQi menyatakan besarnya nilai location quotient sektor i di suatu wilayah

$\Rightarrow$ vi menyatakan jumlah output/tenaga kerja dari industri i di suatu wilayah

$\Rightarrow$ vt menyatakan jumlah total output/tenaga kerja yang ada di suatu wilayah

$\Rightarrow$ Vi menyatakan jumlah output/tenaga kerja dari industri i di wilayah referensi

$\Rightarrow$ Vt menyatakan jumlah total output/tenaga kerja yang ada di wilayah referensi.

Nilai yang ditunjukkan pada rumusan LQ ini akan memiliki arti seperti pada aturan di bawah ini :

$\Rightarrow$ Jika nilai LQi > maka sektor i di wilayah tersebut lebih terspesialisasi dibandingkan dengan sektor yang sama pada wilayah referensi atau dengan kata lain sektor tersebut merupakan sektor yang mampu mengekspor produknya/tenaga kerjanya (sektor basis)

$\Rightarrow$ Jika nilai LQi $<1$ maka sektor i di wilayah tersebut kurang terspesialisasi dibandingkan dengan sektor yang sama pada wilayah referensi atau dengan kata lain sektor tersebut merupakan sektor yang tidak mampu untuk mengekspor produknya/ tenaga kerjanya (sektor nonbasis)

$\Rightarrow$ Jika nilai LQi = 1 maka sektor i di wiayah tersebut memiliki tingkat spesialisasi yang sama dibandingkan dengan sektor yang sama pada wilayah referensi atau dengan kata lain sektor tersebut merupakan sektor mampu memenuhi kebutuhan wilayahnya sendiri.

\section{Analisis Shift Share}

Analisis shift-share merupakan teknik yang sangat berguna dalam menganalisis perubahan ekonomi wilayah dibandingkan 
dengan perekonomian wilayah yang lebih luas (wilayah referensi) selama selang waktu tertentu. Tujuan dari analisis Shift Share ini adalah untuk menentukan kinerja atau produktivitas kerja perekonomian wilayah dengan membandingkannya dengan wilayah yang lebih luas (Bagdja Muljarijadi, 2016:59).

Selanjutnya masih dari Baggdja Muljarijadi (2016: 59-60), menyebutkan bahwa analisis ini memberikan data tentang kinerja perekonomian ke dalam tiga bidang yang berhubungan satu sama lainnya, yaitu :

a) Pertumbuhan ekonomi (economic growth) yang diukur dengan cara menganalisis perubahan pengerjaan agregat secara sektoral dibandingkan dengan perubahan pada sektor yang sama di perekonomian yang menjadi acuan/referesi.

b) Pergeseran proporsional (Proportional shift), yang mengukur perubahan relatif, tumbuh lebih cepat atau lebih lambat, suatu sektor di wilayah dibandingkan dengan perekonomian yang lebih besar yang dijadikan acuan (nasional).

c) Pergeseran differential (Differential shift), digunakan dalam menentukan seberapa jauh daya saing sektoral suatu wilayah dibandingkan dengan perekonomian yang dijadikan acuan.

\section{Analisis SWOT}

Analisis SWOT adalah identifikasi berbagai faktor secara sistematis untuk merumuskan strategi perusahaan. Analisis ini didasarkan pada logika yang dapat memaksimalkan kekuatan (Strengths) dan peluang (Opportunities), namun secara bersamaan dapat meminimalkan kelemahan (Weaknesses) dan ancaman (Threats). Proses pengambilan keputusan strategis selalu berkaitan dengan pengembangan misi, tujuan, strategi dan kebijakan perusahaan. Dengan demikian, perencanaan strategic (strategic planner) harus menganalisis faktor-faktor strategi perusahaan (kekuatan, kelemahan, peluang, dan ancaman) dalam kondisi yang ada saat ini (Rangkuti, 2017: 1920).

Selanjutnya Rangkuti (2017: 20), menyebutkan bahwa analisis SWOT membandingkan antara faktor eksternal Peluang (opportunities) dan Ancaman (threats) dengan faktor internal Kekuatan (strengths), dan kelemahan (weaknesses).

\begin{tabular}{|l|l|}
\hline \multicolumn{2}{|c|}{ BERBAGAI PELUANG } \\
$\begin{array}{l}\text { 3. Mendukung } \\
\text { Strategi turn- } \\
\text { around }\end{array}$ & $\begin{array}{l}\text { 1. Mendukung } \\
\text { strategi agresif }\end{array}$ \\
$\begin{array}{l}\text { KELEMAHAN } \\
\text { INTERNAL }\end{array}$ & $\begin{array}{l}\text { KEKUATAN } \\
\text { INTERNAL }\end{array}$ \\
$\begin{array}{l}\text { 4. Mendukung } \\
\text { Strategi } \\
\text { defensif }\end{array}$ & $\begin{array}{l}\text { 2. Mendukung } \\
\text { strategi } \\
\text { diversifikasi }\end{array}$ \\
\multicolumn{1}{|c|}{ BERBAGAI ANCAMAN } \\
\hline
\end{tabular}

Gambar-1

ANALISIS SWOT

Kuadran-1 : Ini merupakan situasi yang sangat menguntungkan. Perusahaan tersebut memiliki peluang dan kekuatan sehingga dapat memanfaatkan peluang yang ada. Strategi yang harus dikembangkan dalam kondisi ini adalah mendukung kebijakan pertumbuhan yang agresif (growth oriented strategy).

Kuadran-2 : meskipun menghadapi berbagai ancaman, perusahaan ini masih memiliki kekuatan dari segi internal. Strategi yang harus diterapkan adalah menggunakan kekuatan untuk memanfaatkan peluang jangka panjang dengan cara strategi diversifikasi (produk/ pasar)

Kuadran-3 : Perusahaan menghadapi 
peluang pasar yang sangat besar, tetapi di lain pihak, ia menghadapi beberapa kendala/kelemahan internal.

Kuadran-4 : Ini merupakan situasi yang sangat tidak menguntungkan, perusahaan tersebut menghadapi berbagai ancaman dan kelemahan internal.

Chang (2015) di dalam penelitiannya, menggunakan analisis SWOT berdasarkan European Creativity Index's (ECI) enam pilar kreativitas untuk mengukur propek kota Penang sebagaikotakreatif. Keenam pilartersebutadalah : opennes diversity, human capital, technology, Institutional environtment, social \& cultural, dan pilar terakhir adalah creative output. Dari enam pilar tersebut sebagai indikator kreativitas, kemudian dijabarkan dengan menggunakan SWOT ke dalam analisis kekuatan internal (strenghts), kelemahan internal (weaknesses), peluang eksternal (opportunities), dan ancaman eksternal (threats).

BEKRAF (2016) menerbitkan buku panduan pemeringkatan kabupaten/kota kreatif, menyebutkan ada tujuh dimensi yang dapat digunakan sebagai indikator pemeringkatan ekonomi kreatif kabupaten/kota. Hamdan (2016), juga menyebutkan tujuh dimensi untuk mengetahui daya saing ekonomi kreatif. Ketujuh dimensi tersebut adalah: sumber daya manusia, sumber daya alam \& budaya, daya saing industri, pembiayaan, pemasaran, infrastruktur dan teknologi, regulasi dan kelembagaan.

\section{METODE PENELITIAN}

Metode penelitian menggunakan data sekunder untuk melihat data perekonomian tangerang selatan dengan menggunakan data PDRB kota Tangerang Selatan dan provinsi Banten. Data BPS dan dokumen lain yang digunakan adalah sebagai berikut :

1. Produk Domestik Regional Bruto Kota Tangerang Selatan Menurut Lapangan Usaha 2012 - 2016

2. Produk Domestik Regional Bruto Provinsi Banten Menurut Lapangan Usaha 2012 -
2017

3. Indikator Ekonomi Kota Tangerang Selatan $2015-2016$

4. Buku Saku PDRB Provinsi Banten, PDRB Kabupaten/Kota se Banten, PDRB Provinsi se Jawa, dan PDRB Indonesia, 2015-2016.

5. Rencana Strategis (RENSTRA) 2016 2021, Pemerintah Kota Tangerang Selatan.

6. Rencana Kerja Pembangunan Daerah Tangerang Selatan, 2017

7. Sumber dan referensi lain yang berkaitan dengan penelitian.

\section{Analisis LQ (Location Quotient)}

Untuk menganalisis perekonomian dan sektor unggulan, selain menggunakan data BPS, dilakukan juga perhitungan LQ dan Shift Share. Rumus yang digunakan untuk analisis LQ adalah sebagai berikut :

Dimana :

vi : PDRB sektor (i) kota Tangerang Selatan

vt : PDRB total sektor (i) kota Tangerang Selatan

Vi : PDRB sektor (i) provinsi Banten

$\mathrm{Vt}$ : PDRB total sektor (i) provinsi Banten

\section{Analisis Shift Share}

Perhitungan Shift Share yang digunakan oleh BPS (BPS, Indikator Kota Tangerang Sela$\tan 2015 / 2016)$, adalah sebagai berikut :

$\Delta \mathrm{Y} \mathrm{r}, \mathrm{i}, \mathrm{t}=(\mathrm{Psi}+\mathrm{Sp} \mathrm{r,i}+\mathrm{Sd} \mathrm{r,i})$

Dimana :

$\Delta \mathrm{Y}=$ Perubahan Nilai Tambah Bruto (NTB tahun $\mathrm{t}-\mathrm{NTB}$ tahun $\mathrm{t}-\mathrm{n}$ )

$\mathrm{P}=$ Provincial atau wilayah yang lebih luas

$\mathrm{r}=$ region atau wilayah analisis

$\mathrm{i}=$ sektor PDRB

$\mathrm{t}=$ tahun

PS $=$ Provincial Share

$\mathrm{P}=$ Proportional Shift

D = Differential Shift 


\section{Komponen Analisis Shift Share :}

\section{Provincial Share}

Yaitu seandainya pertambahan Nilai Tambah Bruto Regional sektor (i) sama dengan proporsi pertambahan nilai bruto secara rata-rata.

Ps i,t $=$ Y r,i,t-n X (Y N,t / Y N. t-n ) - Y, r,i, t-n)

\section{Proportional Shift}

Yaitu melihat sektor (i) secara nasional terhadap pertumbuhan Nilai Tambah Bruto sektor (i) secara region yang di analisis.

P r,i,t $=\{(Y N$ i,t $/$ Y N,i,t-n $)-(Y N, t / Y$ N,t-n) \} X Y, r,i,t-n)

\section{Differential Shift}

Menggambarkan penyimpangan antara pertumbuhan sektor (i) di wilayah analisis terhadap pertumbuhan sektor i secara nasional (pengaruh keunggulan komparatif).

D r,i,t = Y r,i,t - (Y N,i,t / Y N,i,t-n) X Y r,i,t-n). Perhitungan Shift Share yang digunakan

di dalam penelitian ini mengadopsi model perhitungan Shift Share yang dilakukan Widyaningsih (2010) pada penelitiannya, karena penggunaan simbol rumus yang lebih sederhana. Model persamaan tersebut dengan simbol formulasi yang berbeda bisa dituliskan sebagai berikut :

$\mathrm{PR}=\mathrm{RS}+\mathrm{S}$

Dimana: $\mathrm{PR}=$ Pertumbuhan Nasional $/$ Regional

RS = National/Regional Share

$\mathrm{S}=$ Share

Persamaan tersebut dapat ditulis :

$\mathrm{S}=\mathrm{PR}-\mathrm{RS}$

$\mathrm{PR}=\left(\epsilon_{r t}^{i}-\epsilon_{r n}^{i}\right)$

$\mathrm{RS}=\epsilon_{r 0}^{i}\left(\epsilon_{n t /} \epsilon_{n 0}\right)-\epsilon_{r 0}^{i}$

Dimana :

$\epsilon_{r 0}^{i}=$ PDRB Tangerang Selatan sektor i tahun awal observasi

$\epsilon_{r t}^{i}=$ PDRB Tangerang Selatan sektor i tahun akhir observasi

$\epsilon_{n 0}=$ PDB Banten tahun awal observasi

$\epsilon_{n t}=$ PDB Banten tahun akhir observasi
Persamaan Differential Shift (DS) :

$$
\mathrm{DS}=\sum\left\{\left(\frac{\epsilon_{r t}^{i}}{\epsilon_{r 0}^{i}}\right)-\left(\frac{\epsilon_{n t}^{i}}{\epsilon_{n 0}^{i}}\right)\right\} \epsilon_{r 0}^{i}
$$

Persamaan Proportional Shift (PS) :

$$
\mathrm{PS}=\sum\left\{\left(\frac{\epsilon_{n t}^{i}}{\epsilon_{n 0}^{i}}\right)-\left(\frac{\epsilon_{n t}}{\epsilon_{n 0}}\right)\right\} \epsilon_{r 0}^{i}
$$

\section{Analisis SWOT}

Analisis SWOT Analisis SWOT merupakan salah satu metode untuk menggambarkan kondisi dan mengevaluasi suatu masalah, proyek atau konsep bisnis berdasarkan faktor internal dan eksternal. Analisis SWOT juga dapat dikatakan sebagai instrumen analisis yang digunakan dalam pendekatan manajemen strategis untuk mencari strategi terpilih dan juga tepat yang akan digunakan oleh seseorang atau suatu badan dalam upaya mencapai tujuan yang diharapkan dalam jangka waktu (Widyningsih, 2010).

Rangkuti (2017) menyebutkan di dalam penyusunan perencanaan strategis dengan menggunakan analisis SWOT, ada 3 tahapan analisis yang dilakukan, yaitu :

1. Tahap pengumpulan data. Pada tahap ini dilakukan pengumpulan data, pengklasifikasian dan pra-analisis. Pada tahap ini dilakukan evaluasi faktor eksternal dan evaluasi faktor internal.

2. Tahap analisis. Setelah mengumpulkan semua informasi yang berpengaruh, tahap selanjutnya adalah memanfaatkan semua informasi ke dalam model matriks SWOT agar dapat memperoleh analisis yang lebih lengkap dan akurat.

3. Tahap pengambilan keputusan. Pada tahap ini adalah merumuskan strategi apa yang paling tepat dari grand strategi faktorfaktor internal maupun eksternal yang sudah ditetapkan (SO, WO, ST,WT). 


\begin{tabular}{|l|l|l|}
\hline IFAS & STRENGTHS (S) & WEAKNESSES (W) \\
EFAS & $\begin{array}{l}\text { Tentukan faktor-faktor kekuatan } \\
\text { internal }\end{array}$ & $\begin{array}{l}\text { Tentukan faktor-faktor kelemahan } \\
\text { internal }\end{array}$ \\
\hline OPPORTUNITIES (O) & STRATEGI (SO) & STRATEGI (WO) \\
Tentukan faktor peluang eksternal & $\begin{array}{l}\text { Ciptakan strategi yang } \\
\text { menggunakan kekuatan untuk strategi yang } \\
\text { memanfaatkan peluang }\end{array}$ & $\begin{array}{l}\text { meminimalkan kelemahan untuk } \\
\text { memanfaatkan peluang }\end{array}$ \\
\hline THREATS (T) & $\begin{array}{l}\text { STRATEGI (ST) } \\
\text { Tentukan faktor ancaman eksternal }\end{array}$ & $\begin{array}{l}\text { Ciptakan strategi yang } \\
\text { menggunakan kekuatan untuk } \\
\text { mengatasi ancaman }\end{array}$ \\
\hline
\end{tabular}

Sumber : Rangkuti (2017)

Gambar-2

Matriks SWOT

Analisis SWOT ini digunakan untuk mengetahui potensi ekonomi kreatif dan pengembangan serta strategi ekonomi kreatif Tangerang Selatan. Data yang digunakan adalah data sekunder dari berbagai dokumen dan literatur, seperti publikasi data BPS/ Statistik, dokumen laporan ekonomi kreatif, artikel, sumber berita dari website terkait, dan dokumen lainnya yang relevan terkait ekonomi kreatif.

Pada penelitian ini digunakan tujuh dimensi indikator ekonomi kreatif yang kemudian di analisis dengan menggunakan SWOT untuk menganalisis kekuatan faktor internal, (strenghts), kelemahan faktor internal (weaknesses), peluang faktor eksternal (opportunities), dan ancaman faktor eksternal (threats). Berdasarkan analisis ini agar dapat diketahui potensi, pengembangan dan strategi ke depan ekonomi kreatif kota Tangerang Selatan. Ketujuh dimensi tersebut adalah : sumber daya manusia, sumber daya alam \& budaya, daya saing industri, pembiayaan, pemasaran, infrastruktur dan teknologi, regulasi dan kelembagaan.

\section{PEMBAHASAN \\ Pertumbuhan Ekonomi}

Laju pertumbuhan ekonomi Tangerang Selatan menunjukkan tren menurun dari tahun 2012 - tahun 2016. Pada tahun 2012 laju pertumbuhan sempat mencatat di angka 8,66 persen, kemudian mencapai angka yang paling rendah di tahun 2016 menjadi 6,98 persen (angka sangat sementara). Pertumbuhan tertinggi di tahun 2016 berdasarkan lapangan usaha adalah di sektor pengolahan listrik dan Gas, yaitu mencapai 13,21 persen. Sementara di sektor industri pengolahan mengalami penurunan yang drastis, yaitu $(0,33)$ persen di tahun 2016.

Pertumbuhan yang tinggi di sektor pengolahan listrik dan gas menunjukkan adanya pembangunan perumahan yang meningkat di daerah kota tangerang selatan, sehingga adanya permintaan terhadap listrik dan gas. Sejalan dengan hal ini ditunjang dengan adanya peningkatan pengadaan air, pengelolaan sampah, limbah dan daur ulang yang menunjukkan pertumbuhan yang meningkat.

Jika dibandingkan dengan pertumbuhan 
provinsi Banten, pertumbuhan ekonomi secara keseluruhan menurut lapangan usaha, pertumbuhan ekonomi Tangerang Selatan relatif lebih tinggi dibandingkan dengan provinsi Banten untuk tahun 2012 - 2016. Laju pertumbuhan ekonomi provinsi Banten 2012 - 2016 menunjukkan tren yang sama, menurun dari 6,83 persen di tahun 2012, menjadi 5,26 persen di tahun 2016.

Tabel-3

Laju Pertumbuhan Ekonomi Kota Tangerang Selatan dan Provinsi Banten Tahun 2012 - 2016 Berdasarkan Harga Konstan 2010

\begin{tabular}{|c|c|c|c|c|c|c|c|c|c|c|c|}
\hline \multirow{3}{*}{\begin{tabular}{|c|} 
NO \\
$\mathrm{A}$ \\
\end{tabular}} & \multirow{3}{*}{\begin{tabular}{|l|} 
LAPANGAN USAHA \\
$\begin{array}{l}\text { Pertanian, Kehutanan } \\
\text { dan Perkebunan }\end{array}$ \\
\end{tabular}} & \multirow{2}{*}{\multicolumn{2}{|c|}{\begin{tabular}{|c|c|} 
Tangsel & Banten \\
2012 \\
\end{tabular}}} & \multirow{2}{*}{\multicolumn{2}{|c|}{\begin{tabular}{|c|c|} 
Tangsel & Banten \\
2013 \\
\end{tabular}}} & \multirow{2}{*}{\multicolumn{2}{|c|}{\begin{tabular}{|c|c|} 
Tangsel & Banten \\
2014
\end{tabular}}} & \multirow{2}{*}{\multicolumn{2}{|c|}{\begin{tabular}{|c|c|} 
Tangsel & Banten \\
2015
\end{tabular}}} & \multirow{2}{*}{\multicolumn{2}{|c|}{\begin{tabular}{|c|} 
Tangsel $\mid$ Banten \\
2016 \\
\end{tabular}}} \\
\hline & & & & & & & & & & & \\
\hline & & $-2,59$ & 3,20 & $-1,65$ & 6,73 & 3,04 & 2,45 & 2,1 & 6,53 & 0,1 & 7,05 \\
\hline $\mathrm{B}$ & $\begin{array}{l}\text { Pertambangan dan } \\
\text { Penggalian }\end{array}$ & - & $-0,04$ & - & $-6,21$ & - & 3,69 & - & 3,66 & - & 3,43 \\
\hline $\mathrm{C}$ & Industri pengolahan & 0,72 & 4,75 & 8,34 & 7,81 & 6,95 & 1,7 & 3,82 & 3,44 & $-0,33$ & 3,05 \\
\hline \multirow[t]{2}{*}{$\mathrm{D}$} & $\begin{array}{l}\text { Pengadaan Listrik dan } \\
\text { Gas }\end{array}$ & 12,00 & 3,46 & 10,37 & $-3,43$ & 5,63 & 8,26 & 1,29 & $-1,39$ & 13,21 & $-4,14$ \\
\hline & $\begin{array}{l}\text { Pengadaan Air, } \\
\text { Pengelolahan sampah, }\end{array}$ & & & & & & & & & & \\
\hline $\mathrm{E}$ & Limbah dan Daur Ulang & 0,85 & 0,53 & 5,59 & 3,44 & 6,35 & 7,15 & 5,03 & 5,16 & 6,21 & 6,83 \\
\hline $\mathrm{F}$ & Konstruksi & 12,66 & 10,81 & 12,52 & 9,99 & 7,14 & 11,46 & 6,63 & 8,47 & 9,2 & 6,09 \\
\hline \multirow{2}{*}{$\mathrm{G}$} & \multirow{2}{*}{$\begin{array}{l}\text { Perdagangan Besar, } \\
\text { Eceran, Reparasi }\end{array}$} & 9,50 & 9,33 & 6,35 & 5,4 & 4,42 & 6,04 & 5,76 & 4,75 & 4,75 & 3,82 \\
\hline & & & & & & & & & & & \\
\hline $\mathrm{H}$ & $\begin{array}{l}\text { Transportasi dan } \\
\text { pergudangan }\end{array}$ & 9,42 & 9,49 & 10,93 & 4,15 & 12,44 & 5,42 & 8,36 & 6,32 & 8,13 & 7,6 \\
\hline I & $\begin{array}{l}\text { Penyediaan akomodasi } \\
\text { dan Makan Minum }\end{array}$ & 5,10 & 5,54 & 6,13 & 3,89 & 7,75 & 8,83 & 6,47 & 6,41 & 7,61 & 7,55 \\
\hline $\mathrm{J}$ & $\begin{array}{l}\text { Informas1 dan } \\
\text { Komunikasi }\end{array}$ & 18,26 & 14,47 & 10,98 & 8,03 & 16,42 & 18,71 & 10,15 & 9,81 & 9,12 & 8,52 \\
\hline K & $\begin{array}{l}\text { Jasa Keuangan dan } \\
\text { Asuransi }\end{array}$ & 6,74 & 10,82 & 7,81 & 8,65 & 8,43 & 4,75 & 8,58 & 8,4 & 7,77 & 14,16 \\
\hline $\mathrm{L}$ & Real Estate & 9,41 & 8,11 & 11,62 & 7,32 & 8,19 & 8,42 & 8,54 & 6,68 & 8,71 & 7,48 \\
\hline \multirow{2}{*}{$\mathrm{MN}$} & Jasa perusahaan & 9,03 & 7,21 & 9,83 & 7,64 & 11,2 & 8,78 & 10,36 & 7,97 & 9,57 & 7,49 \\
\hline & \begin{tabular}{|l} 
Administrasi \\
Pemerintahan,
\end{tabular} & & & & & & & & & & \\
\hline $\mathrm{O}$ & $\begin{array}{l}\text { dan Jaminan sosial } \\
\text { wajib }\end{array}$ & 4,57 & 6,20 & 2,22 & 1,03 & 10,09 & 8,18 & 8,72 & 6,55 & 8,41 & 7,11 \\
\hline $\mathrm{P}$ & Jasa Pendididikan & 3,54 & 4,17 & 4,69 & 3,94 & 5,71 & 7,57 & 8,18 & 6,35 & 7,9 & 6,8 \\
\hline $\mathrm{Q}$ & $\begin{array}{l}\text { Jasa Kesenatan dan } \\
\text { Kegiatan Sosial }\end{array}$ & 4,18 & 5,30 & 1,51 & 1,65 & 2,72 & 6,34 & 4,12 & 5,24 & 7,47 & 7,14 \\
\hline $\begin{array}{l}\mathrm{R}, \mathrm{S}, \\
\mathrm{T}, \mathrm{U}\end{array}$ & Jasa lainnya & 1,75 & 2,55 & 6,61 & 6,88 & 4,16 & 7,49 & 5,78 & 6,54 & 7,84 & 7,39 \\
\hline & \begin{tabular}{|l|} 
PERTUMBUHAN \\
EKONOMI - PDRB \\
TANGSEL, ADHK \\
2010
\end{tabular} & 8,66 & 6,83 & 8,75 & 6,67 & 8,05 & 5,51 & 7,20 & 5,4 & 6,98 & 5,26 \\
\hline
\end{tabular}

Sumber : BPS, PDRB Tangerang Selatan dan Provinsi Banten 2012 - 2016, ADHK 2010

\section{Struktur Ekonomi}

Untuk dapat melihat struktur ekonomi suatu daerah, dapat dilihat dari berapa besar kontribusi berdasarkan lapangan usaha ter- hadap PDRB. BPS menyebutkan bahwa perekonomian suatu daerah dapat dibagi menjadi 3 kelompok lapangan usaha, yaitu kelompok usaha primer, sekunder dan jasa. Kelompok 
lapangan usaha primer terdiri dari lapangan usaha pertanian, kehutanan dan perikanan; Pertambangan dan Penggalian. Kelompok lapangan usaha sekunder terdiri dari lapangan usaha industri pengolahan; pengadaan listrik dan gas; pengadaan air; Konstruksi. Kelompok lapangan usaha tersier terdiri dari lapangan usaha perdagangan besar dan reparasi mobil dan sepeda motor; transportasi dan pergudangan; penyediaan akomodasi makan dan minum; informasi dan komunikasi; jasa keuangan; real estate; jasa perusahaan.

Sektor primer memberikan kontribusi paling kecil. Untuk sektor pertanian, kehutanan dan perikanan hanya memberikan kontribusi rata-rata selama periode 2012 - 2016 sebesar 0,26 persen. Sementara kota tangerang selatan tidak memiliki sektor pertambangan dan penggalian. Di sektor sekunder, kontribusi terbesar masing-masing diberikan oleh sektor konstuksi dan industri pengolahan dengan kontribusi terhadap PDRB masing-masing sebesar 13,09 persen dan 11,13 persen. Untuk sektor tersier, kontribusi terbesar adalah di sektor lapangan kerja di sektor perdagangan besar, eceran, reparasi mobil dan sepeda motor, dan real estate masing-masing rata-rata sebesar 17,67 persen dan 17,64 persen.

Tabel-4

PDRB Tangerang Selatan 2012 - 2016

\begin{tabular}{|c|l|r|r|r|r|r|r|}
\hline \multirow{2}{*}{ NO } & \multicolumn{2}{|c|}{ LAPANGAN USAHA } & \multicolumn{5}{|c|}{ Share Lapangan Us aha terhadap PDRB } \\
\cline { 3 - 8 } & & $\mathbf{2 0 1 2}$ & $\mathbf{2 0 1 3}$ & $\mathbf{2 0 1 4}$ & $\mathbf{2 0 1 5}$ & $\mathbf{2 0 1 6}$ & Rata-rata \\
\hline A & Pertanian, Kehutanan dan & $0,30 \%$ & $0,27 \%$ & $0,26 \%$ & $0,24 \%$ & $0,23 \%$ & $0,26 \%$ \\
\hline B & Perkebunan & $0,00 \%$ & $0,00 \%$ & $0,00 \%$ & $0,00 \%$ & $0,00 \%$ & $0,00 \%$ \\
\hline C & Industri pengolahan & $11,53 \%$ & $11,49 \%$ & $11,37 \%$ & $11,01 \%$ & $10,26 \%$ & $11,13 \%$ \\
\hline D & Pengadaan Listrik dan Gas & $0,10 \%$ & $0,11 \%$ & $0,10 \%$ & $0,10 \%$ & $0,10 \%$ & $0,10 \%$ \\
\hline & $\begin{array}{l}\text { Pengadaan Air, Pengelolahan } \\
\text { sampah, }\end{array}$ & & & & & & \\
\hline E & Limbah dan Daur Ulang & $0,05 \%$ & $0,05 \%$ & $0,05 \%$ & $0,05 \%$ & $0,05 \%$ & $0,05 \%$ \\
\hline F & Konstruksi & $12,78 \%$ & $13,22 \%$ & $13,11 \%$ & $13,04 \%$ & $13,31 \%$ & $13,09 \%$ \\
\hline G & $\begin{array}{l}\text { Perdagangan Besar, Eceran, } \\
\text { Reparasi }\end{array}$ & $18,53 \%$ & $18,12 \%$ & $17,51 \%$ & $17,27 \%$ & $16,92 \%$ & $17,67 \%$ \\
\hline & Mobil dan Sepeda Motor & & & & & & \\
\hline H & Transportasi dan pergudangan & $2,70 \%$ & $2,75 \%$ & $2,87 \%$ & $2,90 \%$ & $2,93 \%$ & $2,83 \%$ \\
\hline I & $\begin{array}{l}\text { Penyediaan akomodasi dan Makan } \\
\text { Minum }\end{array}$ & $3,04 \%$ & $2,97 \%$ & $2,96 \%$ & $2,94 \%$ & $2,96 \%$ & $2,98 \%$ \\
\hline J & Informasi dan Komunikasi & $13,82 \%$ & $14,11 \%$ & $15,19 \%$ & $15,60 \%$ & $15,92 \%$ & $14,93 \%$ \\
\hline K & Jasa Keuangan dan Asuransi & $1,17 \%$ & $1,16 \%$ & $1,16 \%$ & $1,18 \%$ & $1,19 \%$ & $1,17 \%$ \\
\hline L & Real Estate & $17,12 \%$ & $17,57 \%$ & $17,60 \%$ & $17,82 \%$ & $18,11 \%$ & $17,64 \%$ \\
\hline MN & Jasa perusahaan & $3,03 \%$ & $3,06 \%$ & $3,15 \%$ & $3,24 \%$ & $3,32 \%$ & $3,16 \%$ \\
\hline & $\begin{array}{l}\text { Administrasi Pemerintahan, } \\
\text { Pertahanan }\end{array}$ & $1,02 \%$ & $0,96 \%$ & $0,98 \%$ & $1,00 \%$ & $1,01 \%$ & $0,99 \%$ \\
\hline O & dan Jaminan sosial wajib & & & & & & \\
\hline P & Jasa Pendididikan & $7,40 \%$ & $7,12 \%$ & $6,97 \%$ & $7,03 \%$ & $7,09 \%$ & $7,12 \%$ \\
\hline Q & Jasa kesehatan dan Kegiatan Sosial & $4,54 \%$ & $4,24 \%$ & $4,03 \%$ & $3,91 \%$ & $3,93 \%$ & $4,13 \%$ \\
\hline R,S,T,U & Jasa lainnya & $2,86 \%$ & $2,80 \%$ & $2,70 \%$ & $2,67 \%$ & $2,69 \%$ & $2,74 \%$ \\
\hline
\end{tabular}

Sumber : BPS, PDRB Tangerang Selatan 2012 - 2016 
Berdasarkan kelompok usaha, kontribusi terbesar terhadap PDRB kota tangerang selatan adalah kelompok usaha sektor tersier atau jasa. Tahun 2016, kelompok usaha sektor tersier menyumbang 73,93 persen, sementara sektor sekunder sebesar 25,81 persen dan paling kecil adalah sektor primer, yaitu hanya sebesar 0,26 persen saja.

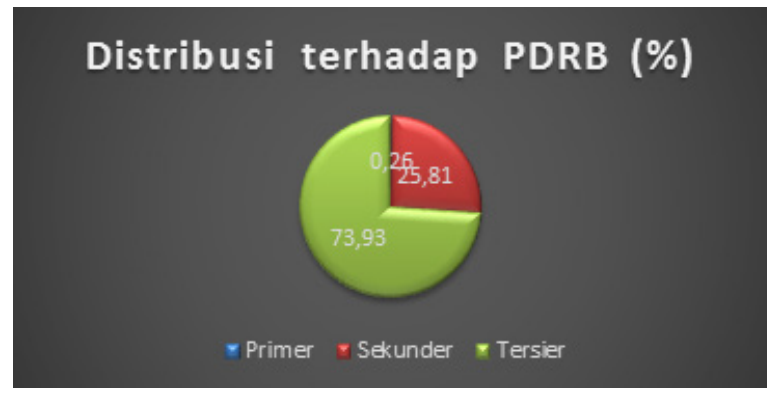

Sumber : BPS - PDRB Tangerang Selatan 2016

Gambar-3

Distribusis PDRB Tangerang Selatan 2016

\section{Analisis LQ (Location Quotient)}

Analisis LQ adalah salah satu metode yang digunakan untuk mengindentifikasi tahap awal terhadap keunggulan komparatif suatu daerah. Berdasarkan perhitungan LQ akan diketahui sektor apa saja yang memiliki peranan besar dalammenunjang pembangunan perekonomian suatu daerah melalui indentifikasi sektor basis dan non-basis (Widyaningsih, 2010).
Berdasarkan data LQ kota tangerang selatan berdasarkan PDRB 2012 - 2016, ada sembilan lapangan usaha yang menjadi sektor unggulan, atau sektor basis dengan nilai LQ $>1$. Sembilan sektor unggulan tersebut adalah Konstruksi; Perdagangan besar, Eceran, Reparasi Mobil dan Motor; Penyediaan akomodasi makan dan minum; Informasi dan Komunikasi; Real Estate; Jasa Perusahaan; Jasa Pendidikan; Jasa Kesehatan dan Kegiatan Sosial; dan Jasa Lainnya.

\section{Analisis Shift Share}

Berdasarkan perhitungan Shift Share kota Tangerang Selatan terhadap provinsi Banten kurun waktu 2012 - 2016, di dapat pertumbuhan aktual (PR), atau total perubahan Nilai Tambah Bruto sebesar Rp. 12.545.576,04 juta. Sementara nilai Regional Share (RS) antara perekonomian kota Tangerang Selatan dengan provinsi Banten secara total adalah sebesar Rp. 11.308.256,10 juta. Angka ini menunjukkan bertambahnya Nilai Tambah Bruto atau laju pertumbuhan yang dicapai kota tangerang selatan sama dengan pertambahan Nilai Tambah Bruto, atau laju pertumbuhan provinsi Banten. Nilai Regional Share lebih besar dari nilai pertumbuhan kota Tangerang Selatan, hal ini menunjukkan bahwa secara keseluruhan pertumbuhan kota Tangerang Selatan relatif lebih cepat dibandingkan pertumbuhan provinsi Banten.

Tabel-5

Kontribusi per sektor Lapangan usaha dan Nilai LQ 2012 - 2016

Sumber : BPS, diolah

\begin{tabular}{|c|c|c|c|c|c|c|c|c|c|c|c|}
\hline \multirow[b]{2}{*}{ No } & \multirow[b]{2}{*}{ LAPANGAN USAHA } & \multicolumn{2}{|c|}{2012} & \multicolumn{2}{|c|}{2013} & \multicolumn{2}{|c|}{2014} & \multicolumn{2}{|c|}{2015} & \multicolumn{2}{|c|}{2016} \\
\hline & & Kontribusi & Nilai LQ & Kontrribusi & Nilai LQ & Kontrribusi & Nilai LQ & Kontrribusi & Nilai LQ & Kontribus & i Nilai LQ \\
\hline A & $\begin{array}{l}\text { Pertanian, Kehutanan dan } \\
\text { Perkebunan }\end{array}$ & $0,30 \%$ & 0,05 & $0,27 \%$ & 0,05 & $0,26 \%$ & 0,05 & $0,24 \%$ & 0,04 & $0,23 \%$ & 0,01 \\
\hline $\mathrm{B}$ & Pertambangan dan Penggalian & $0,00 \%$ & 0 & $0,00 \%$ & 0 & $0,00 \%$ & 0 & $0,00 \%$ & 0 & $0,00 \%$ & 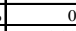 \\
\hline $\mathrm{C}$ & Industri pengolahan & $11,53 \%$ & 0,30 & $11,49 \%$ & 0,30 & $11,37 \%$ & 0,30 & $11,01 \%$ & 0,30 & $10,26 \%$ & 0,01 \\
\hline \multirow[t]{2}{*}{$\mathrm{D}$} & Pengadaan Listrik dan Gas & $0,10 \%$ & 0,01 & $0,11 \%$ & 0,09 & $0,10 \%$ & 0,08 & $0,10 \%$ & 0,08 & $0,10 \%$ & 0,10 \\
\hline & $\begin{array}{l}\text { Pengadaan Air, Pengelolahan } \\
\text { sampah, }\end{array}$ & & & & & & & & & & \\
\hline $\mathrm{E}$ & Limbah dan Daur Ulang & $0,05 \%$ & 0,54 & $0,05 \%$ & 0,54 & $0,05 \%$ & 0,01 & $0,05 \%$ & 0,01 & $0,05 \%$ & 0,01 \\
\hline $\mathrm{F}$ & Konstruksi & $12,78 \%$ & 1,54 & $13,22 \%$ & 1,54 & $13,11 \%$ & 1,45 & $13,04 \%$ & 1,40 & $13,31 \%$ & 1,42 \\
\hline \multirow[t]{2}{*}{ G } & $\begin{array}{l}\text { Perdagangan Besar, Eceran, } \\
\text { Reparasi }\end{array}$ & $18,53 \%$ & 1,36 & $18,12 \%$ & 1,35 & $17,51 \%$ & 1,29 & $17,27 \%$ & 1,29 & $16,92 \%$ & 1,28 \\
\hline & Mobil dan Sepeda Motor & & & & & & & & & & \\
\hline $\mathrm{H}$ & \begin{tabular}{|l|} 
Transportasi dan pergudangan \\
\end{tabular} & $2,70 \%$ & 0,42 & $2,75 \%$ & 0,44 & $2,87 \%$ & 0,46 & $2,90 \%$ & 0,46 & $2,93 \%$ & 0,45 \\
\hline I & $\begin{array}{l}\text { Penyediaan akomodasi dan } \\
\text { Makan Minum }\end{array}$ & $3,04 \%$ & 1,33 & $2,97 \%$ & 1,34 & $2,96 \%$ & 1,29 & $2,94 \%$ & 0,47 & $2,96 \%$ & 1,25 \\
\hline $\mathrm{J}$ & Informasi dan Komunikasi & $13,82 \%$ & 3,04 & $14,11 \%$ & 3,06 & $15,19 \%$ & 2,93 & $15,60 \%$ & 2,89 & $15,92 \%$ & 2,86 \\
\hline $\mathrm{K}$ & Jasa Keuangan dan Asuransi & $1,17 \%$ & 0,44 & $1,16 \%$ & 0,43 & $1,16 \%$ & 0,43 & $1,18 \%$ & 0,43 & $1,19 \%$ & 0,40 \\
\hline $\mathrm{L}$ & Real Estate & $17,12 \%$ & 2,23 & $17,57 \%$ & 2,28 & $17,60 \%$ & 2,22 & $17,82 \%$ & 2,22 & $18,11 \%$ & 2,21 \\
\hline \multirow[t]{2}{*}{ MN } & Jasa perusahaan & $3,03 \%$ & 3,29 & $3,06 \%$ & 3,29 & $3,15 \%$ & 3,29 & $3,24 \%$ & 3,30 & $3,32 \%$ & 3,31 \\
\hline & $\begin{array}{l}\text { Administrasi Pemerintahan, } \\
\text { Pertahanan }\end{array}$ & $1,02 \%$ & 0,58 & $0,96 \%$ & 0,58 & $0,98 \%$ & 0,57 & $1,00 \%$ & 0,58 & $1,01 \%$ & 0,57 \\
\hline $\mathrm{O}$ & dan Jan & & & & & & & & & & \\
\hline $\mathrm{P}$ & Jasa Pendid & $7,40 \%$ & 2,57 & $7,12 \%$ & 2,54 & $6,97 \%$ & 2,44 & $7,03 \%$ & 2,44 & $7,09 \%$ & 2,42 \\
\hline $\mathrm{Q}$ & $\begin{array}{l}\text { Jasa kesehatan dan Kegiatan } \\
\text { Sosial }\end{array}$ & $4,54 \%$ & 3,79 & $4,24 \%$ & 3,71 & $4,03 \%$ & 3,50 & $3,91 \%$ & 3,41 & $3,93 \%$ & 2,30 \\
\hline $\mathrm{S}, \mathrm{T}, \mathrm{t}$ & Jasa lainnya & $2,86 \%$ & 2,08 & $2,80 \%$ & 2,04 & $2,70 \%$ & 1,93 & $2,67 \%$ & 1,88 & $2,69 \%$ & 1,86 \\
\hline
\end{tabular}


Nilai S > DS, menunjukkan kota Tangerang Selatan berspesialisasi pada sektor-sektor yang pertumbuhannya pada tingkat provinsi tinggi.

Nilai Differential Shift (DS) kota Tangerang Selatan terhadap Banten adalah sebesar Rp. 1.607.192,14 juta, mempunyai nilai positif. Hal ini merupakan akibat keunggulan komparatif beberapa sektor yang cukup tinggi dari kota Tangerang Selatan atau tumbuh lebih cepat dibandingkan pertumbuhan provinsi Banten. Keunggulan komparatif kota Tangerang Selatan dibandingkan dengan provinsi Banten, terlihat hampir pada semua sektor, kecuali untuk sektor Pertanian, Kehutanan dan Perkebunan; Konstruksi; Jasa Keuangan dan Asuransi; Jasa Kesehatan dan Kegiatan Sosial; dan Jasa Lainnya.
Nilai Proportional Shift (PS) kota Tangerang Selatan secara keseluruhan adalah sebesar Rp. 1.960.387,83 juta. Hal ini menunjukkan bahwa kota Tangerang Selatan hampir di semua kategori memiliki komposisi sektor-sektor industri secara proporsional tumbuh lebih cepat dibandingkan dengan provinsi Banten. Nilai PS yang negatif ada pada Industri Pengolahan; Pengadaan Listrik dan Gas; Pengadaan Air, Pengelolaan Sampah, Limbah dan Daur Ulang; Perdagangan Besar, Eceran, Reparasi Mobil dan Sepeda Motor; Administrasi Pemerintahan, Pertahanan dan Jaminan Sosial Wajib; Jasa Kesehatan dan Kegiatan Sosial. Nilai PS negatif menunjukkan proporsi pertambahan Nilai Tambah Bruto kategori sektor tersebut dari Tangerang Selatan terhadap PDRB Banten rendah.

Tabel-6

Nilai Shift Share PDRB Tangerang Selatan terhadap PDRB Banten

\begin{tabular}{|c|c|c|c|c|c|c|}
\hline NO & LAPANGAN USAHA & PR & RS & $\underline{\mathbf{S}}$ & DS & PS \\
\hline A & Pertanian, Kehutanan dan Perkebuna & $3.845,42$ & $26.538,02$ & $-22692,59889$ & $-22692,60$ & $-189,19$ \\
\hline $\mathrm{B}$ & Pertambangan dan Penggalian & - & 0 & 0 & - & 0,00 \\
\hline $\mathrm{C}$ & Industri pengolahan & $828.778,45$ & 702454,1576 & 126324,2924 & $126.324,29$ & $-332853,76$ \\
\hline \multirow[t]{2}{*}{$\mathrm{D}$} & Pengadaan Listrik dan Gas & $12.762,67$ & $-441,0347725$ & 13203,70477 & $13.203,70$ & $-9865,60$ \\
\hline & $\begin{array}{l}\text { Pengadaan Air, Pengelolahan } \\
\text { sampah, }\end{array}$ & & & 0 & - & 0,0 \\
\hline E & Limbah dan Daur Ulang & $4.740,79$ & 4599,068644 & 141,7213561 & 141,72 & $-67,88$ \\
\hline $\mathrm{F}$ & Konstruksi & $1.861 .903,21$ & 1894476,468 & $-32573,25842$ & $32.573,26$ & 747112,51 \\
\hline \multirow[t]{2}{*}{$\mathrm{G}$} & Perdagangan Besar, Eceran, Reparas & $1.540 .354,13$ & 1440651,121 & 99703,00896 & $99.703,01$ & $-222737,77$ \\
\hline & Mobil dan Sepeda Motor & & & 0 & & 0,00 \\
\hline $\mathrm{H}$ & Transportasi dan pergudangan & $449.522,42$ & 249456,7241 & 200065,6959 & $200.065,70$ & 7091,83 \\
\hline I & $\begin{array}{l}\text { Penyediaan akomodasi dan Makan } \\
\text { Minum }\end{array}$ & $340.730,23$ & 323135,1278 & 17595,10222 & $17.595,10$ & 4 \\
\hline $\mathrm{J}$ & Informasi dan Komunikasi & $2.752 .010,14$ & 2634997,307 & 117012,8326 & \begin{tabular}{|l|}
$117.012,83$ \\
\end{tabular} & 1394019,01 \\
\hline $\mathrm{K}$ & Jasa Keuangan dan Asuransi & $155.294,54$ & 172403,9972 & $-17109,45722$ & $17.109,46$ & 67391,44 \\
\hline $\mathrm{L}$ & Real Estate & $2.626 .541,38$ & 2064234,04 & 562307,3401 & $562.307,34$ & 527067,38 \\
\hline \multirow[t]{2}{*}{$\mathrm{MN}$} & Jasa perusahaan & $521.123,72$ & 392280,2795 & 128843,4405 & $128.843,44$ & 120366,75 \\
\hline & $\begin{array}{l}\text { Administrasi Pemerintahan, } \\
\text { Pertahanan }\end{array}$ & $120.706,43$ & & 120706,43 & $490.578,63$ & $-461879,54$ \\
\hline $\mathrm{O}$ & dan Jaminan sosial wajib & & 0 & 0 & 1 & 0,00 \\
\hline $\mathrm{P}$ & Jasa Pendididikan & $778.843,57$ & 720705,0025 & 58138,56746 & $58.138,57$ & 56655,72 \\
\hline $\mathrm{Q}$ & Jasa kesehatan dan Kegiatan Sosial & $273.163,04$ & 358386,1791 & $-85223,13912$ & $85.223,14$ & $-49245,76$ \\
\hline \multirow[t]{3}{*}{$\mathrm{R}, \mathrm{S}, \mathrm{T}, \mathrm{U}$} & \begin{tabular}{|l|} 
Jasa lainnya \\
\end{tabular} & $275.255,90$ & 324379,6457 & $-49123,74569$ & $49.123,75$ & 67641,47 \\
\hline & & & & & & \\
\hline & TOTAL & $12.545 .576,04$ & $11.308 .256,10$ & $1.237 .319,94$ & $1.607 .192,14$ & $1.960 .387,83$ \\
\hline
\end{tabular}

Sumber : BPS, diolah

\section{Potensi Ekonomi Kreatif}

Potensi ekonomi kreatif Tangerang Selatan cukup besar. Berdasarkan analisis sektor unggulan, sub-sektor ekonomi kreatif masuk ke dalam sembilan sektor unggulan Tangerang Selatan, yaitu Konstruksi; Perdagangan besar, Eceran, Reparasi Mobil dan Motor; Penyediaan akomodasi makan dan minum; Informasi dan
Komunikasi; Real Estate; Jasa Perusahaan; Jasa Pendidikan; Jasa Kesehatan dan Kegiatan Sosial; dan Jasa Lainnya.

Berdasarkan data IKM 2017 Tangerang Selatan, bidang kuliner merupakan bidang dengan tingkat perkembangan yang tertinggi, yaitu sebanyak $884(51,8 \%)$, kemudian diikuti masing-masing sebanyak $276(16,2 \%)$ di bidang 
konveksi/fashion, sebanyak 209 (12,2\%) di bidang furniture, dan sebanyak $112(6,6 \%)$ di bidang jasa (Disperindag, Tangsel, 2017).

Berdasarkan data dinas pariwisata Tangerang Selatan yang disajikan secara kreatif melalui video oleh Febriani (2017), prosentasi pelaku ekonomi kreatif di daerah Tangerang Selatan, terbesar berada di Kecamatan Serpong, yaitu sebesar 26,6 persen, kemudian berturutturut berada pada Kecamatan Pamulang sebesar 25,9 persen, Pondok Aren (18,2 persen), Ciputat dan Serpong Utara masing-masing sebesar 9,8 persen, Ciputat Timur sebesar 7 persen dan Kecamatan Setu sebesar 2,8 persen. Sementara dari 16 sub-sektor ekonomi kreatif, bidang kuliner menempati urutan pertama, yaitu sebesar 39,2 persen, kemudian diikuti oleh Kriya (16,1 persen), Fashion (9,1 \%), televisi dan radio $(6,3 \%)$, penerbitan dan desain interior masing-masing sebesar $4,9 \%$, musik $3,5 \%$, seni pertunjukan $(2,8 \%)$, fotografi, aplikasi \&game developer, dan arsitektur masing-masing sebesar $2,1 \%$, dan untuk sub-sektor desain produk, desain komunikasi visual, periklanan, dan seni rupa masing-masing sebesar $1,4 \%$.

\section{Analisis SWOT \\ Berdasarkan data dan informasi yang dikumpulkan dari berbagai dokumen, beri- kut adalah analisis Strength, Weaknesses, Opportunities, dan Threats potensi ekonomi kreatif kota Tangerang Selatan.}

Tabel-7

Analisis SWOT Potensi Ekonomi Kreatif Tangerang Selatan

\begin{tabular}{|c|c|c|}
\hline Dimensi & Strength & Weakness \\
\hline \multirow{4}{*}{$\begin{array}{l}\text { Sumber Daya } \\
\text { Manusia }\end{array}$} & $\begin{array}{l}\text { Indeks Pembangunan Manusia Tangerang } \\
\text { Selatan tertinggi dibandingkan dengan } \\
\text { kabupaten/kota se Banten, yaitu sebesar } \\
79,38 \% \text { (BPS, 2015) }\end{array}$ & $\begin{array}{l}\text { Belum banyak tersedia pendidikan } \\
\text { yang mengajarkan mata kuliah, modul } \\
\text { ketrampilan terkait ekonomi kreatif, } \\
\text { seperti fashion, teknologi informasi, } \\
\text { animasi, film dan video, dan lainnya } \\
\text { terkait ekonomi kreatif }\end{array}$ \\
\hline & $\begin{array}{l}\text { Kelompok Jumlah Penduduk usia } \\
\text { produktif terbesar, yaitu } 1.109 .920 \text { jiwa, } \\
\text { atau } 71,92 \% \text { (BPS, 2015) }\end{array}$ & $\begin{array}{l}\text { Tingkat kompotensi dan skill yang masih } \\
\text { rendah, terutama di bidang teknologi dan } \\
\text { informasi, entrepreneurship, manajemen, } \\
\text { proses produksi dan keahlian lain di } \\
\text { bidang ekonomi kreatif }\end{array}$ \\
\hline & $\begin{array}{l}\text { Kelompok penduduk usia } 15 \text { tahun ke } \\
\text { atas menamatkan pendidikan SMA/ } \\
\text { Sederajat ke atas atau sebesar 60,54\% } \\
\text { merupakan modal utama menjalankan } \\
\text { pembangunan (BPS, 2015) }\end{array}$ & \\
\hline & $\begin{array}{l}\text { Memiliki banyak talenta-talenta kreatif } \\
\text { masyarakat urban yang berdomisi di } \\
\text { Tangerang Selatan (iKreatif, 2015) }\end{array}$ & \\
\hline \multirow{2}{*}{$\begin{array}{l}\text { Sumber Daya Alam } \\
\text { dan Budaya }\end{array}$} & $\begin{array}{l}\text { Memiliki potensi di bidang seni dan } \\
\text { budaya, seperti Sanggar seni puspo } \\
\text { budoyo, Kandang Jurang Doang sebagai } \\
\text { rumah kreativitas, Budaya Betawi, dan } \\
\text { pengadaan even secara }\end{array}$ & $\begin{array}{l}\text { Tangerang selatan minim akan sumber } \\
\text { daya alam }\end{array}$ \\
\hline & $\begin{array}{l}\text { Potensi warisan budaya seperti makanan } \\
\text { khas/kuliner asli Tangerang Selatan, batik } \\
\text { tangsel yang sudah mulai dikenal }\end{array}$ & $\begin{array}{l}\text { Warisan budaya asli Tangerang Selatan } \\
\text { perlu dijaga dan dilestarikan, termasuk } \\
\text { fasilitas dan penggiat seni budaya asli } \\
\text { tangerang selatan }\end{array}$ \\
\hline
\end{tabular}




\begin{tabular}{|c|c|c|}
\hline \multirow{3}{*}{ Daya Saing Industri } & \begin{tabular}{|l|} 
Tangerang Selatan mempunyai daya \\
saing daerah dengan luas zona industri \\
seluas 2218,31 hektar dengan 2386 unit \\
industri yang termanfaatkan, infrastruktur \\
jalan dan transportasi, Fasilitas \\
perdagangan dan jasa,serta kualitas \\
sumber daya manusia yang baik (RPJMD \\
2016 -2021)
\end{tabular} & $\begin{array}{l}\text { Ekonomi kreatif tangerang selatan } \\
\text { masih relatif baru, sehingga daya saing } \\
\text { di bidang kelembagaan, pemasaran, } \\
\text { pembiayaan, infrastruktur dan teknologi, } \\
\text { industri, bahan baku, sumber daya kreatif } \\
\text { masih rendah }\end{array}$ \\
\hline & \begin{tabular}{|l|} 
memiliki jumlah IKM/UKM yang cukup \\
besar, yaitu sebanyak +/- 1708 industri. \\
Dan sebanyak $51 \%$ adalah industri \\
makanan (disperindag tangsel) \\
\end{tabular} & \\
\hline & \begin{tabular}{|l|} 
Beberapa produk ekonomi kreatif sudah \\
diikut sertakan di dalam pameran produk \\
ekonomi kreatif di Luar negeri, seperti \\
Cina, Meksiko, Jerman (diolah dari \\
berbagai sumber) \\
\end{tabular} & \\
\hline \multirow{2}{*}{ Pembiayaan } & $\begin{array}{l}\text { Peran pemerintah kota tangerang selatan } \\
\text { di dalam membantu pembiayaan UKM/ } \\
\text { UMKM, bekerja sama dengan Bank-bank } \\
\text { yang ada di wilayah Tangerang Selatan } \\
\end{array}$ & $\begin{array}{l}\text { Belum banyak tersedia sumber } \\
\text { pembiayaan dan tidak semua sub-sektor } \\
\text { ekonomi kreatif mendapatkan fasilitas } \\
\text { pembiayaan }\end{array}$ \\
\hline & \begin{tabular}{|l|} 
Tangerang Selatan mendapatkan \\
penghargaan sebagai kota terbaik dan \\
kota potensial untuk kategori INVESTASI, \\
Attractiveness Award 2017.
\end{tabular} & \\
\hline \multirow[t]{2}{*}{ Pemasaran } & $\begin{array}{l}\text { Sering diselenggarakan festival dan } \\
\text { pameran industri kreatif baik di dalam } \\
\text { negeri maupun di luar negeri, khususnya } \\
\text { untuk produk IKM/UKM ekonomi kreatif }\end{array}$ & $\begin{array}{l}\text { Belum banyak tersedia informasi dan } \\
\text { akses pasar yang diketahui oleh pelaku } \\
\text { ekonomi kreatif }\end{array}$ \\
\hline & $\begin{array}{l}\text { Peran aktif pemkot tangerang selatan } \\
\text { membantu pemasaran hasil IKM/UKM } \\
\text { dan produk ekonomi kreatif lainnya }\end{array}$ & $\begin{array}{l}\text { Proses pemasaran hasil ekonomi kreatif } \\
\text { IKM/UKM masih dilakukan secara } \\
\text { konvensional }\end{array}$ \\
\hline \multirow{3}{*}{$\begin{array}{l}\text { Infrastruktur dan } \\
\text { Teknologi }\end{array}$} & $\begin{array}{l}\text { Tangerang Selatan sebagai kota yang } \\
\text { mencanangkan smart city, memiliki } \\
\text { potensi pengembangan teknologi } \\
\text { informasi dan teknologi untuk } \\
\text { mengakomodasi pertumbuhan ekonomi } \\
\text { kreatif. }\end{array}$ & $\begin{array}{l}\text { Ketrampilan dan pengetahuan Sumber } \\
\text { Daya Manusia masih belum optimal di } \\
\text { dalam penggunaan Informasi, Teknologi } \\
\text { dan Komunikasi }\end{array}$ \\
\hline & $\begin{array}{l}\text { Fasilitas infrastruktur yang memadai } \\
\text { untuk pelaku ekonomi kreatif melakukan } \\
\text { meeting, konferensi dan ajang pameran } \\
\text { produk ekonomi kreatif }\end{array}$ & \\
\hline & $\begin{array}{l}\text { Tangerang selatan bekerja sama dengan } \\
\text { TELKOM membangun kampung digital } \\
\text { untuk membantu pemasaran secara } \\
\text { online. }\end{array}$ & \\
\hline \multirow{3}{*}{$\begin{array}{l}\text { Regulasi dan } \\
\text { Kelembagaan }\end{array}$} & $\begin{array}{l}\text { Sudah dibentuknya SKPD bidang } \\
\text { ekonomi kreatif kota tangerang selatan } \\
\text { pada tahun bulan Januari 2017, di bawah } \\
\text { Dinas Pariwisata Tangsel }\end{array}$ & $\begin{array}{l}\text { Bidang Ekonomi Kreatif di bawah Dinas } \\
\text { Pariwisata relatif masih baru dibentuk } \\
\text { (2018) }\end{array}$ \\
\hline & \begin{tabular}{|l|} 
Dibentuknya kelembagaan ekonomi \\
kreatif, yaitu MAKET (Masyarakat \\
Kreatif Tangsel) yang bertugas untuk \\
mengembangkan potensi ekonomi kreatif \\
tangsel
\end{tabular} & $\begin{array}{l}\text { Kelembagaan ekonomi kreatif MAKET } \\
\text { relatif masih baru dibentuk, yaitu pada } \\
\text { bulan Desember } 2017\end{array}$ \\
\hline & $\begin{array}{l}\text { Tangerang Selatan mendapatkan } \\
\text { penghargaan Laporan Hasil Evaluasi } \\
\text { Akuntabilitas Kinerja Instansi Pemerintah } \\
\text { (LHE-AKIP) }\end{array}$ & $\begin{array}{l}\text { Pelaku usaha ekonomi kreatif banyak } \\
\text { belum berbadan hukum }\end{array}$ \\
\hline
\end{tabular}


Tabel-8

Analisis SWOT Potensi Ekonomi Kreatif Tangerang Selatan

\begin{tabular}{|c|c|c|}
\hline Dimensi & Opportunities & Threats \\
\hline \multirow{3}{*}{$\begin{array}{l}\text { Sumber Daya } \\
\text { Manusia }\end{array}$} & $\begin{array}{l}\text { Peran aktif dari Pemerintah melalui Bekraf, } \\
\text { Universitas di dalam memberikan pelatihan } \\
\text { ekonomi kreatif melalui kewirausahaan, } \\
\text { bidang manajemen, bidang produksi, } \\
\text { pengembangan produk, pemasaran dan } \\
\text { promosi, serta penggunaan teknologi } \\
\text { informasi dan komunikasi }\end{array}$ & $\begin{array}{l}\text { Salah satu masalah besar yang dihadapi di } \\
\text { dalam ekonomi kreatif adalah keterbatasan } \\
\text { sumber daya manusia sebagai pelaku } \\
\text { ekonomi kreatif, baik dari sisi jumlah, } \\
\text { pengetahuan, keahlian, kemampuan proses } \\
\text { produksi, desain,kemampuan manajerial, } \\
\text { dan pengetahuan teknologi informasi } \\
\end{array}$ \\
\hline & $\begin{array}{l}\text { Peran Universitas di lingkungan wilayah } \\
\text { Tangerang Selatan di dalam mengkader } \\
\text { dan melakukan pembimbingan calon- } \\
\text { calon pebisnis melalui inkubator bisnis } \\
\text { dan inkubator teknologi, serta pusat-pusat } \\
\text { inovasi yang dipelopori oleh BPPT Serpong } \\
\text { Tangerang Selatan }\end{array}$ & \\
\hline & $\begin{array}{l}\text { Adanya potensi bonus demografis } \\
\text { berdasarkan sensus penduduk } 2010 \text {, dimana } \\
\text { sebesar } 60 \% \text { dari total jumlah penduduk } \\
\text { adalah usia produktif ( } 15 \text { - } 55 \text { tahun) dan } \\
27 \% \text { adalah anak muda (16-30 tahun) }\end{array}$ & \\
\hline $\begin{array}{l}\text { Sumber Daya } \\
\text { Alam dan Budaya }\end{array}$ & $\begin{array}{l}\text { Peran aktif pemerintah kota, } \\
\text { universitas, pengusaha dan komunitas } \\
\text { memperkenalkan, memprmosikan produk } \\
\text { asli,warisan budaya sub sektor ekonomi } \\
\text { kreatif Tangerang Selatan baik di dalam } \\
\text { negeri maupun ke luar negeri }\end{array}$ & $\begin{array}{l}\text { Masyarakat Tangerang Selatan terdiri dari } \\
\text { masyarakat asli dan masyarakat urban, } \\
\text { pendatang yang menetap, bisa berdampak } \\
\text { kepada hilangnya budaya asli kota } \\
\text { Tangerang Selatan }\end{array}$ \\
\hline \multirow[t]{2}{*}{$\begin{array}{l}\text { Daya Saing } \\
\text { Industri }\end{array}$} & $\begin{array}{l}\text { Secara nasional industri kreatif masih rendah } \\
\text { pada } 7 \text { dimensi ekonomi kreatif, sumber daya } \\
\text { kreatif, bahan baku, industri, pembiayaan, } \\
\text { pemasaran, infrastruktur dan teknologi, } \\
\text { kelembagaan. Skor tertinggi dicapai pada } \\
\text { pengembangan industri. Dan sektor terendah } \\
\text { pada dimensi pembiayaan (Hamdan, 2016) } \\
\end{array}$ & $\begin{array}{l}\text { Mahalnya biaya bahan baku dan biaya } \\
\text { produksi sehingga mengurangi daya saing } \\
\text { produk }\end{array}$ \\
\hline & $\begin{array}{l}\text { Posisi Global Creativity Index Negara } \\
\text { Indonesia masih pada ururtan ke } 115 \\
\text { (Hamdan, 2016) }\end{array}$ & $\begin{array}{l}\text { masuknya produk dan barang-barang } \\
\text { murah dari Luar Negeri, seperti negara Cina } \\
\text { dan Korea Selatan yang dapat menurunkan } \\
\text { daya saing produk lokal }\end{array}$ \\
\hline Pembiayaan & $\begin{array}{l}\text { Peran aktif Badan Ekonomi Kreatif } \\
\text { (BEKRAF) dan pemerintah kota membantu } \\
\text { memfasilitasi pembiayaan ekonomi kreatif }\end{array}$ & $\begin{array}{l}\text { Kesulitan pelaku ekonomi kreatif untuk } \\
\text { mendapatkan pembiayaan, terutama buat } \\
\text { start up dari Bank, karena produk dari } \\
\text { ekonomi kreatif yang tak berwujud. }\end{array}$ \\
\hline \multirow[b]{2}{*}{ Pemasaran } & $\begin{array}{l}\text { Potensi penggunanaan ICT, internet, dan } \\
\text { e-Commerce sebagai media pemasaran } \\
\text { hasil ekonomi kreatif Tangsel }\end{array}$ & $\begin{array}{l}\text { Tingkat persaingan dari wilayah lain dan } \\
\text { kurangnya promosi yang dilakukan }\end{array}$ \\
\hline & $\begin{array}{l}\text { Peran aktif BEKRAF melalui aplikasi yang } \\
\text { dimiliki, antara lain BISMA membantu } \\
\text { pelaku ekonomi kreatif melakukan } \\
\text { pemasaran produknya }\end{array}$ & $\begin{array}{l}\text { Kurangnya dukungan melakukan riset pasar } \\
\text { atau inovasi produk, sertifikasi dan bantuan } \\
\text { teknologi tepat guna bagi pengusaha IKM/ } \\
\text { UKM ekonomi kreatif untuk meningkatkan } \\
\text { produk dan kapasitas produk-nya }\end{array}$ \\
\hline $\begin{array}{l}\text { Infrastruktur dan } \\
\text { Teknologi }\end{array}$ & $\begin{array}{l}\text { Peran aktif pemerintah melalui BEKRAF } \\
\text { secara terus menerus melakukan pelatihan } \\
\text { di bidang penggunaan teknologi dan } \\
\text { penyediaan fasilitas infrastruktur fisik ruang } \\
\text { bagi pelaku ekonomi kreatif }\end{array}$ & $\begin{array}{l}\text { Ketersediaan SDM pelaku ekonomi kreatif } \\
\text { belum memanfaatkan infrastruktur dan } \\
\text { teknologi secara optimal }\end{array}$ \\
\hline $\begin{array}{l}\text { Regulasi dan } \\
\text { Kelembagaan }\end{array}$ & $\begin{array}{l}\text { Dukungan pemerintah melalui Regulasi } \\
\text { terkait Ekonomi terkait (paket kebijakan } \\
\text { dan UU lain yang mendukung) }\end{array}$ & $\begin{array}{l}\text { Masalah perlindungan terhadap } \\
\text { pembajakan HAKI untuk industri danpelaku } \\
\text { ekonomi kreatif }\end{array}$ \\
\hline
\end{tabular}


Berdasarkan analisis SWOT di atas, dapat dilakukan strategi pengembangan ekonomi kreatif di Tangerang Selatan dengan pendekatan Strength-Opportunities, WeaknessesOpportunities, Strength-Threaths, dan Weaknesses-
Threats untuk masing-masing dimensi.

Pada tabel-9, menunjukkan matrik Strategi Strength-Opportunities, Strategi WeaknessesOpportunities pada tujuh dimensi ekonomi kreatif Tangerang Selatan.

Tabel-9

Matrik Strategi Strength-Opportunities, Strategi Weaknesses-Opportunities

Tujuh Dimensi Ekonomi Kreatif Tangerang Selatan

\begin{tabular}{|c|c|c|}
\hline Dimensi & Strategi S-O & Strategi W-O \\
\hline $\begin{array}{l}\text { Sumber Daya } \\
\text { Manusia }\end{array}$ & $\begin{array}{l}\text { Memberdayakan SDM dengan } \\
\text { kelompok usia produktif, memiliki } \\
\text { IPM relatif tinggi serta talenta-talenta } \\
\text { kreatif untuk mendapatkan pelatihan } \\
\text { kewirausahaan, manajemen, bidang } \\
\text { produksi, pemasaran dan promosi serta } \\
\text { penggunaan ICT, serta melalui pusat } \\
\text { inovasi dan inkubator bisnis untuk dapat } \\
\text { melahirkan calon-calon pebisnis dan } \\
\text { aktor ekonomi kreatif yang tangguh di } \\
\text { Tangerang Selatan }\end{array}$ & $\begin{array}{l}\text { Menyediakan dan memfasilitasi pusat- } \\
\text { pusat pelatihan dan kurikulum pendidikan } \\
\text { terkait ekonomi kreatif, seperti fashion, } \\
\text { teknologi informasi, animasi, film dan } \\
\text { video dan lain-lain terkait ekonomi kreatif }\end{array}$ \\
\hline $\begin{array}{c}\text { Sumber Daya Alam } \\
\text { dan Budaya }\end{array}$ & $\begin{array}{l}\text { Memperbanyak even dan promosi untuk } \\
\text { memperkenalkan budaya asli Tangerang } \\
\text { Selatan baik lokal, nasional maupun } \\
\text { internasional }\end{array}$ & $\begin{array}{l}\text { Warisan budaya asli Tangerang Selatan } \\
\text { harus dijaga dan dilestarikan dengan } \\
\text { memberikan fasilitas serta incentif. } \\
\text { Memperbanyak even, dan promosi }\end{array}$ \\
\hline Daya Saing Industri & $\begin{array}{l}\text { Meningkatkan daya saing dan tingkat } \\
\text { kreativitas pada tujuh dimensi ekonomi } \\
\text { kreatif, terutama kepada SDM dan } \\
\text { dimensi pembiayaan, terutama pada } \\
\text { sektor IKM/UKM }\end{array}$ & $\begin{array}{l}\text { meningkatkan daya saing pada tujuh } \\
\text { dimensi ekonomi kreatif, dengan } \\
\text { menyediakan infrastruktur dan } \\
\text { fasilitas, serta pelatihan SDM dan akses } \\
\text { permodalan kepada pelaku ekonomi } \\
\text { kreatif }\end{array}$ \\
\hline Pembiayaan & $\begin{array}{l}\text { Peran aktif pemerintah pusat dan } \\
\text { daerah membantu pembiayaan dan } \\
\text { meningkatkan investasi ekonomi kreatif, } \\
\text { terutama kepada IKM/UKM ekonomi } \\
\text { kreatif }\end{array}$ & $\begin{array}{l}\text { Memperbanyak akses modal, tidak saja } \\
\text { bersumber dari bank tetapi juga dari } \\
\text { lembaga keuangan non bank }\end{array}$ \\
\hline Pemasaran & $\begin{array}{l}\text { Meningkatkan pemasaran tidak saja } \\
\text { melalui promosi fisik melalui pameran } \\
\text { dan festival, tetapi juga pemanfaatan } \\
\text { ICT, e-Marketing melalui internet, } \\
\text { e-Commerce dan aplikasi lainnya }\end{array}$ & $\begin{array}{l}\text { Memperbanyak informasi dan akses pasar } \\
\text { ekonomi kreatif dengan memanfaatkan } \\
\text { penggunaan informasi Teknologi dan } \\
\text { Informasi, internet, e-Commerce dan } \\
\text { saluran informasi lainnya } \\
\end{array}$ \\
\hline $\begin{array}{l}\text { Infrastruktur dan } \\
\text { Teknologi }\end{array}$ & $\begin{array}{l}\text { Memanfaatkan infrastuktur dan } \\
\text { teknologi yang sudah ada untuk } \\
\text { pengembangan ekonomi kreatif, } \\
\text { serta meningkatkan kerja sama untuk } \\
\text { membangun kampung-kampung } \\
\text { digital }\end{array}$ & $\begin{array}{l}\text { Meningkatkan kualitas SDM terhadap } \\
\text { penggunaan Teknologi Informasi dan } \\
\text { Teknologi }\end{array}$ \\
\hline $\begin{array}{l}\text { Regulasi dan } \\
\text { Kelembagaan }\end{array}$ & $\begin{array}{l}\text { Memberdayakan kelembagaan } \\
\text { ekonomi kreatif serta komunitas } \\
\text { kreatif secara optimal untuk } \\
\text { melakukan terobosan pada tujuh } \\
\text { dimensi ekonomi kreatif, yaitu dimensi } \\
\text { SDM, budaya, daya saing industri, } \\
\text { pemasaran, pembiayaan, infrastruktur } \\
\text { dan teknologi, serta regulasi dan } \\
\text { kelembagaan yang didukung penuh } \\
\text { oleh pemerintah }\end{array}$ & $\begin{array}{l}\text { Mempercepat akselerasi program kerja } \\
\text { kelembagaan dan komunitas ekonomi } \\
\text { kreatif di tingkat daerah yang mendukung } \\
\text { program kerja pemerintah pusat terkait } \\
\text { ekonomi kreatif. Mendorong IKM/UKM } \\
\text { untuk memiliki badan hukum }\end{array}$ \\
\hline
\end{tabular}


Pada tabel-10, menunjukkan matrik Strategi Strength-Threats, Strategi Weaknesses-
Threaths pada tujuh dimensi ekonomi kreatif Tangerang Selatan.

Tabel-10

Matrik Strategi Strength-Threaths, Strategi Weaknesses-Threaths

Tujuh Dimensi Ekonomi Kreatif Tangerang Selatan

\begin{tabular}{|c|c|c|}
\hline Dimensi & Strategi S-T & Strategi $\mathbf{W}-\mathbf{T}$ \\
\hline $\begin{array}{c}\text { Sumber Daya } \\
\text { Manusia }\end{array}$ & $\begin{array}{l}\text { Mengajak dan mempromosikan, } \\
\text { memberikan pelatihan dan memfasilitasi } \\
\text { kegiatan ekonomi kreatif kepada SDM } \\
\text { dengan usia produktif, serta talenta- } \\
\text { talenta kreatif agar dapat menjadi } \\
\text { pelaku-pelaku ekonomi kreatif }\end{array}$ & $\begin{array}{l}\text { Menyediakan program pelatihan } \\
\text { yang terencana, sistematis dan } \\
\text { berkesinambungan serta menambah } \\
\text { kurikulum pelajaran ekonomi kreatif di } \\
\text { lembaga pendidikan formal maupun } \\
\text { informal, memperbanyak even dan } \\
\text { promosi, serta membuat database pelaku } \\
\text { ekonomi kreatif, terutama IKM/UKM } \\
\text { Ekonomi kreatif }\end{array}$ \\
\hline $\begin{array}{c}\text { Sumber Daya Alam } \\
\text { dan Budaya }\end{array}$ & $\begin{array}{l}\text { Kolaborasi antara masyarakat asli dan } \\
\text { masyarakat urban yang memiliki potensi } \\
\text { talenta-talenta kreatif untuk meningkatkan } \\
\text { kreativitas di bidang budaya, dengan tetap }\end{array}$ & $\begin{array}{l}\text { Menyediakan fasilitas dan pelatihan serta } \\
\text { memperkenalkan warisan budaya dengan } \\
\text { mengikutsertakan masyarakat urban } \\
\text { tangerang selatan }\end{array}$ \\
\hline Daya Saing Industri & $\begin{array}{l}\text { Menyediakan dan menyiapkan fasilitas } \\
\text { dan infrastruktur, terutama di dalam } \\
\text { proses produksi. Mulai dari penyediaan } \\
\text { bahan baku sampai dengan proses } \\
\text { produksi menjadi barang akhir }\end{array}$ & $\begin{array}{l}\text { Secara terus menerus meningkatkan daya } \\
\text { saing pada tujuh dimensi ekonomi kreatif, } \\
\text { sementara daya saing masih lemah, perlu } \\
\text { proteksi melalui UU, atau peraturan yang } \\
\text { berpihak terhadap produk barang dan } \\
\text { jasa lokal }\end{array}$ \\
\hline Pembiayaan & $\begin{array}{l}\text { Peran aktif pemerintah pusat dan daerah } \\
\text { membantu mempermudah akses modal } \\
\text { ke Bank, terutama kepada start up IKM/ } \\
\text { UKM ekonomi kreatif }\end{array}$ & $\begin{array}{l}\text { Mempermudah akses terhadap modal } \\
\text { dan pembiayaan serta memperbanyak } \\
\text { saluran modal dan pembiayaan ekonomi } \\
\text { kreatif }\end{array}$ \\
\hline Pemasaran & $\begin{array}{l}\text { peran aktif pemerintah kota Tangerang } \\
\text { Selatan untuk mendorong IKM/UKM } \\
\text { ekonomi kreatif untuk melakukan promosi, } \\
\text { melakukan riset pasar dan inovasi produk }\end{array}$ & $\begin{array}{l}\text { membuka akses informasi pasar, } \\
\text { pelatihan pemasaran dan promosi serta } \\
\text { penggunaan saluran pemasaran secara } \\
\text { online }\end{array}$ \\
\hline $\begin{array}{l}\text { Infrastruktur dan } \\
\text { Teknologi }\end{array}$ & $\begin{array}{l}\text { Mendorong pelaku ekonomi kreatif } \\
\text { memanfaatkan penggunaan Teknologi } \\
\text { Informasi dan Komunikasi }\end{array}$ & $\begin{array}{l}\text { Meningkatkan ketrampilan pelaku ekonomi } \\
\text { kreatif di dalam penggunaan TIK dan } \\
\text { memanfaatkan infrastruktur secara optimal }\end{array}$ \\
\hline $\begin{array}{l}\text { Regulasi dan } \\
\text { Kelembagaan }\end{array}$ & $\begin{array}{l}\text { Memperkuat regulasi masalah } \\
\text { perlindungan terhadap HAKI untuk } \\
\text { industri dan pelaku ekonomi kreatif }\end{array}$ & $\begin{array}{l}\text { Melakukan sosialisasi masalah HAKI } \\
\text { kepada kelembagaan, komunitas, industri } \\
\text { dan pelaku ekonomi kreatif }\end{array}$ \\
\hline
\end{tabular}

Dari analisis strategi SWOT di atas terhadap tujuh dimensi ekonomi kreatif, penulis berpendapat, prioritas utama yang perlu dilakukan adalah pengembangan SDM.

TangerangSelatanmemilikikekuatanpotensi SDM yang berkualitas. Program pelatihan yang terencana, terstruktur, serta berkelanjutan perlu disusun untuk meningkatkan pengetahuan dan ketrampilan pelaku ekonomi kreatif, terutama di bidang kewirausahaan, manajemen, proses produksi, penggunaan teknologi informasi dan komunikasi.
Lembaga perguruan tinggi perlu meningkatkan lagi fungsi inkubator bisnis untuk melahirkan calon-calon pebisnis. Untuk mengatasi adanya hambatan SDM baik secara kualitas maupun kuantitas di sektor ekonomi kreatif, maka perlu diperbanyak modul ketrampilan terkait ekonomi kreatif, seperti fashion, teknologi informasi, animasi, film dan video, dan lainnya terkait ekonomi kreatif.

Prioritaskeduaadalahmasalah pembiayaan. Pemerintah kota Tangerang Selatan cukup aktif membantu IKM/UKM ekonomi kreatif di 
dalam masalah permodalan. Selain itu potensi kota Tangerang Selatan yang mendapatkan penghargaan kota potensial untuk kategori investasi, merupakan kekuatan kota Tangerang Selatan, di dukung dengan peran aktif pemerintah melalui BEKRAF untuk mencari terobosan mengatasi masalah dan hambatan pembiayaan ekonomi kreatif. Hamdan (2016), menyebutkan bahwa daya saing pada tujuh dimensi ekosistem ekonomi kreatif secara keseluruhan masih lemah, dan nilai terendah berada pada dimensi pembiayaan.

\section{KESIMPULAN DAN SARAN \\ Kesimpulan}

Berdasarkan analisis perekonomian, pertumbuhan ekonomi kota Tangerang Selatan untuk periode 2012 - 2016 menunjukkan tren menurun, tetapi jika dibandingkan dengan pertumbuhan ekonomi provinsi Banten, pertumbuhan ekonomi Tangerang Selatan relatif lebih tinggi, yaitu sebesar 6,98\% di tahun 2016, dibandingkan dengan pertumbuhan ekonomi Banten yang hanya sebesar 5,26\%.

Stuktur ekonomi Tangerang Selatan paling besar dikuasai kelompok usaha di bidang jasa (tersier), yang terdiri lapangan usaha perdagangan besar dan reparasi mobil dan sepeda motor; transportasi dan pergudangan; penyediaan akomodasi makan dan minum; informasi dan komunikasi; jasa keuangan; real estate; jasa perusahaan. Kontribusi sektor tersier ini menyumbang $73,93 \%$ terhadap PDRB Tangerang Selatan, sementara sektor sekunder sebesar $25,81 \%$ dan paling kecil adalah sektor primer, yaitu hanya sebesar $0,26 \%$ saja.

Berdasarkan analisis LQ (Location Quotient) terhadap data PDRB 2012-2016 kota Tangerang Selatan ada sembilan lapangan usaha yang menjadi sektor unggulan, atau sektor basis dengan nilai LQ $>1$. Sembilan sektor unggulan tersebut adalah Konstruksi; Perdagangan besar, Eceran, Reparasi Mobil dan Motor; Penyediaan akomodasi makan dan minum; Informasi dan Komunikasi; Real Estate; Jasa Perusahaan;
Jasa Pendidikan; Jasa Kesehatan dan Kegiatan Sosial; dan Jasa Lainnya.

Dari analisis Shift Share kota Tangerang Selatan terhadap provinsi Banten periode tahun 2012-2016, menunjukkan secara keseluruhan pertumbuhan kota Tangerang Selatan relatiflebih tinggi dibandingkan dengan provinsi Banten. Hal ini ditunjukkan dari nilai pertumbuhan aktual (PA) yang lebih besar dari nilai Regional Share (RS). Sementara nilai Differential Shift (DS) positif, menunjukkan keunggulan komparatif beberapa sektor cukup tinggi, kecuali untuk sektor Pertanian, Kehutanan dan Perkebunan; Konstruksi; Jasa Keuangan dan Asuransi; Jasa Kesehatan dan Kegiatan Sosial; dan Jasa Lainnya. Dari nilai Proporsional Shift (PS), juga menunjukkan secara proporsional komposisi sektor-sektor industri tumbuh lebih cepat dibandingkan dengan provinsi Banten.

Potensi ekonomi kreatif Tangerang Selatan cukup besar. Berdasarkan analisis sektor unggulan, sub-sektor ekonomi kreatif bisa dikatakan masuk ke dalam sembilan sektor unggulan perekonomian. Kuliner adalah bidang sub-sektor ekonomi kreatif dengan tingkat perkembangan yang tertinggi, kemudian diikuti oleh sub-sektor konveksi/fashion, furniture dan jasa. Sementara pelaku ekonomi kreatif paling besar berada di tiga kecamatan Serpong, Pamulang dan Pondok Aren.

Dari analisis SWOT dapat dikembangkan lebih lanjut strategi pengembangan ekonomi kreatif kota Tangerang Selatan. Dukungan terhadap pengambangan ekonomi kreatif sangat kuat baik dari pemerintah kota maupun pemerintah pusatmelalui BEKRAF. Berdasarkan tujuh dimensi pengukuran ekonomi kreatif yang digunakan untuk mengukur ekonomi kreatif secara kualitatif melalui analisis SWOT, perlu dikembangkan secara keseluruhan. Dari tujuh dimensi tersebut, ada dua dimensi yang menjadi prioritas dan perhatian. Pertama adalah masalah pengembangan sumber daya manusia dan kedua adalah masalah pembiayaan atau permodalan. 
Saran

Peran pemerintah kota melalui dinas pariwisata bidang ekonomi kreatif, peran komunitas seperti MAKET, lembaga perguruan tinggi dan pelaku ekonomi kreatif menjadi sangat penting dalam pengembangan potensi ekonomi kreatif kota Tangerang Selatan ke depan. Untuk itu perlu adanya kerja sama, koordinasi, komunikasi dan program yang terencana dan sistematik, serta formulasi strategi yang tepat baik jangka pendek maupun jangka panjang.

Penelitian ini merupakan penelitian awal, dan jauh dari sempurna. Untuk itu perlu penelitian lebih lanjut. Untuk penelitian lebih lanjut, dapat di gali lebih dalam lagi, terutama di bidang SDM dan pembiayaan ekonomi kreatif. Dapat juga dilakukan penelitian mengenai model bisnis apa yang tepat digunakan terhadap sub-sektor ekonomi kreatif kota Tangerang Selatan.

\section{DAFTAR PUSTAKA}

Amir Mahmud, 2016, Perekonomian Indonesia Pasca Reformasi, Penerbit Erlangga, Jakarta AR RT Hidayat, A Y Asmara, 2017, Creative industry in supporting economy growth in Indonesia: Perspective of regional innovation system, IOP Conf: Earth and Environment Science, Vol 70, 2017

Bagdja Muljarijadi, 2011, Pembangunan Ekonomi Wilayah Pendekatan Analisis Tabel Input Output, Penerbit Unpad Press, Bandung

Bappeda, Rencana Pembangunan Jangka Menengah Daerah (RPJMD) Kota Tangerang Selatan 2016 - 2021, BAPPEDA Tangerang Selatan

BEKRAF, 2016, Sistem Ekonomi Kreatif Nasional Panduan Pemeringkatan Kabupaten/ Kota Kreatif, Deputi Infrastruktur Badan Ekonomi Kreatif, Jakarta

BEKRAF, 2017, Data Statistik dan Hasil Survey Ekonomi Kreatif, Kerja sama Badan Ekonomi Kreatif dan Badan Pusat Statistik, Badan Ekonomi Kreatif, Jakarta

BEKRAF, 2017, Rencana Strategis Badan
Ekonomi Kreatif 2015 - 2019, Badan

Ekonomi Kreatif, Jakarta

BPS, 2017, Produk Domestik Regional Bruto

Kota Tangerang Selatan Menurut Lapangan

Usaha 2012 - 2016, Badan Pusat Statistik, Tangerang Selatan

BPS, 2017, Produk Domestik Regional Bruto

Provinsi Banten Menurut Lapangan Usaha 2012 - 2016, Badan Pusat Statistik, Banten

BPS, 2016, Indikator Ekonomi Kota Tangerang

Selatan Tahun 2015/2016, Badan Pusat

Statistik, Tangerang Selatan

BPS, 2017, Buku Saku PDRB Provinsi Banten, PDRB Kabupaten/Kota se-Banten, PDRB Provinsi se-Jawa dan PDB Indonesia 2015 2016, Badan Pusat Statistik, Banten

Cita Yustisia Serfiyani, R. Serfianto D. Purnomo, Iswi Hariyani, 2016, Crative Top Secret Ramuan Sukses Bisnis Kreatif Sepanjang Masa, Penerbit Andi, Yogyakarta

Departement Perdagangan Republik Indonesia, 2009, Studi Industri Kreatif Indonesia 2009, Jakarta

DPMPTSP, Rencana Strategis 2016 -2021, Pemerintah Kota Tangerang Selatan Dinas Penanaman Modal dan Pelayanan Terpadu Satu Pintu

Freddy Rangkuti, 2017, Analisis SWOT : Teknik Membedah Kasus Bisnis, PT Gramedia Pustaka Utama, Jakarta

Hamdan, 2016, Kebijakan Dan Strategi Pengembangan Ekonomi Kreatif, Disampaikan dalam kegiatan Study Excursie Mahasiswa Jurusan Ilmu Ekonomi dan Studi Pembangunan Universitas Muhammadiyah Malang, Jakarta

Herie Saksono, 2012, Talenta Baru Pemicu Daya Saing Daerah, Jurnal Bina Praja, Vol 4 No. 2, 2012

http://wartakota.tribunnews.com/2018/01/25/ pemkot-tangerang-dan-tangsel-raihpenghargaan, diakses tgl 04 Maret 2018

http://wartakota.tribunnews.com/2017/09/30/ dua-penghargaan-iaa-untuk-kotatangerang-selatan, diakses tgl 04 Maret 2018 http://indonesiakreatif.bekraf.go.id/ikpro/ 
infographics/pemetaan-daya-saingindustri-kreatif/, diakses tgl 04 Maret 2018 http://disperindag.tangerangselatankota.go.id/ ikm-tangerang-selatan-2017-2/, diakses tgl 05 Maret 2018

https://www.kampungukmdigital.com/directory/ $\mathrm{read} /$ kampung-ukm-digital-keranggan/ tangerang-selatan-punya-kampung-ukmdigital, diakses tgl 05 Maret 2018

http://lisensiuinjkt.com/ekonomi-kreatifdi-indonesia-peluang-dan-tantangan/, diakses tgl 05 Maret 2018

http://www.lpminstitut.com/2014/09/ kebudayaan-tangsel-perlu-perhatian.html, diakses tgl 05 Maret 2018

https://tangerangonline.id/2016/04/11/ produk-ekonomi-kreatif-tangsel-go-tojerman/, diakses tgl 05 Maret 2018

http://blog.indonetwork.co.id/kurangnyakeberpihakan-produk-lokal-kendalakewirausahaan-mandiri/, diakses tgl 06 Maret 2018

https://bisniskini.com/2017/12/23/bekraffasilitasi-pelaku-industri-kreatif/, diakses tgl 06 Maret 2018

http://disperindag.tangerangselatankota.go.id/ ikm-tangerang-selatan-2017/, diakses tgl 06 Maret 2018

iKreatif, 2015, Tangerang Selatan Pelopor Sentra Kuliner Modern, Penerbit PT. Prima Indonesia Kreatif, Vol 2, 2015, Jakarta

Indra Suhendra, Erwin Indrianto, 2014, Kajian Analisis Strategi Pemasaran Produk Unggulan Kota Tangsel, Laporan Akhir, Bagian Perekonomian Sekda Kota Tangerang Selatan

Kusnaeni Widyaningsih, 2010, Analisis Perekonomian Dan Kebijakan Pengembangan Potensi Unggulan Di Kota Bekasi, thesis, Fakultas Ekonomi Universitas Indonesia

Mandra Lazuardi, Mochamad Sandy Triady, 2015, Rencana Pengembangan Kuliner Nasional 2015 - 2019, PT Republik Solusi, Jakarta

Nicole Chang, Suet Leng Khoo, Nurwati
Badarulzaman, Prospect of Penang as a Creative City: A Conceptual Discussion, International Journal of Cultural and Creative Industries, Volume 3, Issue 1, November 2015

Nuraini dan Rifzaldi Nasri, Strategi Pengembangan Industri Kreatif Dengan Pendekatan Triple Helix (Studi Kasus Pada Industri Kreatif Di Tangerang Selatan), Prosiding Seminar Nasional Riset Manajemen \& Bisnis 2017 "Perkembangan Konsep dan Riset E-Business di Indonesia, ISBN: 978602-361-067-9

Pemda Banten, 2016, Rencana Kerja Pembangunan Daerah (RKPD) 2017, Bappeda Kota Tangerang Selatan Tahun Anggaran 2016

Prathama Rahardja, Mandala Manurung, 2014, Teori Ekonomi Makro, Edisi 5, Lembaga Penerbit Fakultas Ekonomi Universitas Indonesia, Jakarta

Sadono Sukirno, 2006, Makro Ekonomi Teori Pengantar, Penerbit Raja Grafindo Persada, Jakarta

Siti Aisah Febriani, Video Ekonomi Kreatif Dinas Pariwisata Kota Tangerang Selatan, Youtube, diakses tgl 04 Maret 2018

Tatang A. Taufik, BPPT, 2013, Mendorong Budaya Inovasi Dan Pengembangan Teknoprener, Bahan Presentasi Pada Semiloka Penguatan Sistem Inovasi, Mengembangkan Bisnis dan Masyarakat Inovasi, Bandung, 23 November, 2013

Yohanes Agatha Engel, Heru Susanto, 2017, Pahlawan Ekonomi Kreatif, Penerbit PT Elex Media Komputindo, Gramedia, Jakarta 